\title{
Article
}

\section{The role of inclusive development and military expenditure in modulating the effect of terrorism on governance}

Asongu, Simplice, Nwachukwu, Jacinta Chikaodi and Le Roux, Sara Available at http://clok.uclan.ac.uk/29443/

Asongu, Simplice, Nwachukwu, Jacinta Chikaodi ORCID: 0000-0003-2987-9242 and Le Roux, Sara (2019) The role of inclusive development and military expenditure in modulating the effect of terrorism on governance. Journal of Economic Studies, 46 (3). pp. 681-709. ISSN 0144-3585

It is advisable to refer to the publisher's version if you intend to cite from the work. http://dx.doi.org/10.1108/JES-11-2017-0343

For more information about UCLan's research in this area go to http://www.uclan.ac.uk/researchgroups/ and search for <name of research Group>.

For information about Research generally at UCLan please go to http://www.uclan.ac.uk/research/

All outputs in CLoK are protected by Intellectual Property Rights law, including Copyright law. Copyright, IPR and Moral Rights for the works on this site are retained by the individual authors and/or other copyright owners. Terms and conditions for use of this material are defined in the policies page. 


\title{
The role of inclusive development and military expenditure in modulating the effect of terrorism on governance
}

\author{
S. Asongu, J. Nwachukwu, S. Le Roux
}

\begin{abstract}
Purpose- The study investigates the role of inclusive human development and military expenditure in modulating the effect of terrorism on governance.

Design/methodology/approach- It is based on 53 African countries for the period 1998-2012 and interactive Generalised Method of Moments is employed. Six governance indicators from the World Bank and two terrorism variables are used, namely: domestic and transnational terrorism dynamics.
\end{abstract}

Findings- The following main findings are established. There is a negative net effect on governance (regulation quality and corruption-control) when inclusive human development is used to reduce terrorism. There is a positive net impact on governance ("voice and accountability" and rule of law) when military expenditure is used to reduce domestic terrorism.

Originality/value- We have complemented the sparse literature on the use of policy variables to mitigate the effect of policy syndromes on macroeconomic outcomes.

JEL Classification: C52; D74; F42; O38 ; P37

Keywords: Terrorism; Inclusive development; Governance; Africa

Acknowledgements

The authors are indebted to the editor and reviewers for their constructive comments.

\section{Introduction}

There are three fundamental motives for assessing the roles of military expenditure and inclusive development in modulating the effect of terrorism on governance in Africa, namely: (i) growing terrorism levels in the continent; (ii) gaps in the literature on the governance-terrorism nexus and (iii) debates in the roles of military expenditure and inclusive development in reducing terrorism. In what follows, we engage the points chronologically.

First, terrorism is flourishing and good governance is deteriorating in Africa (Clavarino, 2014). According to the narrative, poor governance and the mushrooming of 
terrorists' activities in Africa are closely related. Some features of bad governance are also flourishing because of terrorism, notably: vulnerable and corrupt central governments; undertrained and underequipped armies; booming trade in drugs and porous borders. The growth of Islamic fundamentalism in the continent has led to political instability in many regions. Some notable cases include: Ansar Dine, led by a former close ally of Gaddafi, Iyad Ag Ghaly; Ansar Al-Shariya in Tunisia; Al-Qaeda-linked Mulathameen Brigade led by the Algerian Mokhtar Belmokhtar and Al-Qaeda in the Islamic Maghreb (Asongu et al, 2018a).

While the phenomenon of terrorism is not entirely new in the continent, the rate of increase in this trend represents a substantial policy syndrome (Alfa-Wali et al., 2015) ${ }^{1}$. Moreover, while global attention is currently oriented towards the Middle East and pockets of terrorism attacks in Europe, Africa is not receiving the scholarly attention it deserves in spite of growing radicalisation and Islamic fundamentalism (Fazel, 2013; Clavarino, 2014).

Second, while much of the literature has been oriented towards the role of governance in reducing terrorism, very limited research has been focused on the effect of terrorism on governance. Moreover, the literature on whether governance mitigates or promotes terrorism has been the object of intense debate (see Lee, 2013). On the one hand, a strand of the literature is positioned on the fact that governance can mitigate the probability of terrorism by limiting resentment vis-à-vis that State (Li, 2005; Windsor, 2003). On the other hand, another strand of the literature posits that good governance does not reduce terrorism (Gause, 2005), probably because the interests of terrorists' may not be represented in government institutions of democratic politics. Accordingly, nations with a relatively better degree of democracy could host terrorism due to some characteristics in these nations that are compatible with the growth of terrorism. These encompass inter alia: freedom of speech in the expression of disagreement and dissatisfaction by citizens, access and freedom to media and civil liberties (Ross, 1993).

Theories of political access postulate that the nexus between terrorism and good governance is weak (Eyerman, 1998), because of characteristics like: more feasible conditions for the management of conflicts (Li, 2005); respect of the rule of law (Choi, 2010) and judicial independence (Findley \& Young, 2011). Conversely, another branch of the literature is of the position that terrorism is more likely to be associated with government instability and poor

\footnotetext{
${ }^{1}$ According to Fosu (2013), policy syndromes represent conditions that are detrimental to economic prosperity, notably: 'administered redistribution', 'state breakdown', 'state controls', and 'suboptimal inter temporal resource allocation'. Asongu and Nwachukwu (2017a) consider policy syndrome as economic prosperity that is not inclusive whereas with regards to Asongu (2017), understand the concept in terms of knowledge economy gaps. Within the framework of this paper, policy syndromes are terrorism dynamics, notably: domestic terrorism and transnational terrorism.
} 
governance (Piazza, 2008a; Lai, 2007). The latter view is in accordance with a broad stream of studies (Piazza, 2007; Schmid, 1992; Eubank \& Weinberg, 1994). The underlying literature hinges on reverse causality in order to articulate how the extant literature on the positioning of this study is sparse.

The sparse literature on causality flowing from terrorism to governance (Section 2.3) has established that terrorism affects political parties (Indridason, 2008), election anticipations (Berrebi \& Klor, 2006; Siqueira \& Sandler, 2007), "voice and accountability" and political stability/no violence (Indridason, 2008; Williams, 2012), political governance (Jacobson, 2003; Langer \& Cohen, 2005), the outcome of political elections (Kibris, 2010), economic governance (Tabor, 2016), the rule of law (Efobi \& Asongu (2016) and most dimensions of World Governance Indicators negatively (Asongu \& Nwachukwu, 2017b). We complement the underlying literature by introducing policy variables of inclusive development and military expenditure in the assessment of how these policy variables can be used to mitigate the established negative effect of terrorism on governance. Such positioning also contributes to the scholarly debate on the relevance of these policy variables in fighting terrorism.

Third, the literature on the role of policy in reducing terrorism has been mixed at best. Some notable policy tools include military expenditure and inclusive development. While some theoretical and empirical evidence on the linkage between military expenditure and terrorism is inconclusive with negative, positive and insignificant effects (Feridun \& Shahbaz, 2010), other theoretical and empirical literature on the linkage between inclusive development and poverty on terrorism is also conflicting. Accordingly, there is no linkage between terrorism and economic development (Krueger \& Maleckova, 2003); a negative relationship between terrorism and economic development $(\mathrm{Li}, 2005)$; the absence of causality flowing from human development to terrorism (Piazza, 2006); more likelihood of terrorism in poor nations (Abadie, 2006); a positive relationship between terrorism and economic development when victims' views are accounted-for (Gassenbner \& Luechinger, 2011); minority discrimination in the economy not positively influencing domestic terrorism (Piazza, 2011) and the positive relationship between economic development and transnational terrorism (Blomberg et al., 2014). Ultimately, there is mild empirical support for the positive nexus between terrorism and poverty, with the exceptions of Li and Schaub (2004) and Piazza (2011).

The present study integrates the three main strands above by: positioning the inquiry on Africa, assessing the effect of terrorism on governance and investigating the role of 
inclusive development and military expenditure in modulating the effect of terrorism on governance. For this purpose the study employs six governance indicators representing: political governance (political stability/non violence, voice and accountability), economic governance (government effectiveness and regulation quality) and institutional governance (corruption-control and the rule of law).

The research question the study aims to answer is therefore the following: how do military expenditure and inclusive development modulate the effect of terrorism on governance? In order to address this question, the approach to net effect from interactive regressions is employed because it is consistent with the recent literature on the use of policy variables to modulate the effect of policy syndromes on development outcomes (Asongu, 2018).

The rest of the study is organised as follows: The theoretical underpinnings are discussed in Section 2. The data and methodology are engaged in Section 3, while Section 4 presents and discusses the results. Section 5 concludes with future research directions.

\section{Theoretical underpinnings}

\subsection{Governance and terrorism}

While there are several papers on measuring governance (Jong-a-Pin, 2009; Langbein \& Knack, 2010; Bang \& Mitra, 2011; Kuncic, 2013), the focus of the current study is on the Kaufmann et al. (2010) governance indicators from the World Bank because of their wide usage in the literature, especially because they do not map distinctly into single, unique concepts (Langbein \& Knack, 2010) ${ }^{2}$. While some overlap may be apparent, especially given their high substitution from the perspective of correlation coefficients and exploratory factor analysis (Bang \& Mitra, 2011; Kuncic, 2013), there are conceptual differences in the measurement of the variable that should be articulated. Political governance (voice and accountability and political stability/non violence) is defined as the election and replacement of political leaders. Economic governance (regulation quality and government effectiveness) is the formulation and implementation of policies that deliver public commodities. Institutional governance (corruption-control and the rule of law) is defined as the respect by the State and citizens of institutions that govern interactions between them.

Terrorism, according to Enders and Todd (2006), is the threatened use of force by sub-national actors for the goal of employing intimidation to secure political goals. Therefore, the

\footnotetext{
${ }^{2}$ In the interest of brevity, the interested reader can find more insights into why these governance indicators enjoy wide usage in Asongu (2016).
} 
definition and conception of terrorism is designed to affect political governance, negatively or positively. Within the framework of this study, we dispute that the linkage can be extended to other dimensions of governance, namely: institutional and economic governances. On the one hand, institutional governance can be affected by terrorism when the State and/or citizens fail to respect institutions that govern interactions between them. On the other hand, economic governance can be influenced by terrorism because violent mechanisms can be employed to manifest grievances on the poor formulation and implementation of measures that deliver public goods.

The theoretical foundations connecting governance and terrorism can be engaged in three principal strands: links between governance and domestic terrorism; the relationship between transnational terrorism and governance and debates surrounding the relationship.

First, consistent with Choi (2010), the nexus between domestic terrorism and governance is based on the perspective that ordinary citizens are endowed with incentives to utilise violence against political figures, government institutions and other citizens, under three scenarios, notably, when citizens: have grievances; find no pacific mechanisms by which to quell their sentiments of desperation and hopelessness and; view the use of terror tactics as a viable and legitimate means of communicating their frustration and anger. The foundations of this postulation rest on the intuition that terrorism can be employed by citizens as means towards influencing government policies when no pacific alternatives are available. Hence, within these circumstances, in order to manifest their grievances, citizens are likely to use terrorism mechanisms to influence institutional, economic and political governances.

Second, with respect to the nexus between governance and transnational terrorism, good governance is expected to reinforce institutional, economic and political governances and to also provide nonviolent avenues by which grievances can be attenuated (see Choi, 2010).

In addition, domestic governments can be influenced by transnational terrorism in view of improving standards of government in order to further prevent contagion of domestic conflicts and terrorism. The theoretical governance-'transnational terrorism' linkage is feasible because foreign policy can be influenced by transnational terrorism. This narrative aligns with the results of Savun and Phillips (2009) who demonstrate that regardless of types of political regimes, transnational terrorism is linked with foreign policy because a foreign policy of a nation affects resentment abroad and transnational terrorism is a mechanism by which domestic governments can be influenced to change their foreign policies. 
With the understanding of above narratives, it is logical to postulate that terrorism can influence, inter alia: (i) institutional governance or the respect by citizens and the State of institutions that govern interactions between them; (ii) economic governance or the formulation and implementation of policies that provide public goods to citizens and (iii) political governance or free and fair democratic process for the election and replacement of political leaders.

The theoretical foundations on the relationship between governance and terrorism in the third strand are conflicting. Consistent with Hoffman et al. (2013), inquiries into the nexus between governance and cross-national terrorism are based on the scholarship that violent mechanisms can be employed to exploit differences in regime-types. Within this scenario, it is more likely that terrorism is used to influence bad governance, compared to good governance. Nonetheless, it is relevant to balance the narrative with the perspective that there are more opportunities available for citizens to air their grievances within the framework of good governance. Conversely, the liberties offered by good governance with democratic institutions can be abused by recalcitrant citizens who might yet employ violence to resolve their grievances.

It is also interesting to note that violence is more likely to be employed as a mechanism of influencing governance in failing and/or failed states relative to autocracies that enjoy relative stability (Piazza 2008a; Lai, 2007; Piazza, 2007; Drakos \& Gofas, 2006; Eubank \& Weinberg, 1994; Schmid, 1992). Conversely, theories of political access postulate that the nexus between terrorism and good governance is weak (Eyerman, 1998), because of characteristics like: more feasible conditions for the management of conflicts (Li, 2005); respect of the rule of law (Choi, 2010) and judicial independence (Findley \& Young, 2011).

The empirical literature has also substantially documented the linkage between governance institutions and transnational terrorism (Lee, 2013; Piazza, 2007, 2008b; Eubank \& Weinberg, 1994, 2001; Weinberg \& Eubank, 1998). Chenoweth (2010) has argued that good governance that is characterised by democratic competition can avail feasible conditions for violence. Two competing effects on the role of democracy are apparent (see Li, 2005): Government constraints can boost transnational terrorism due to deadlock from checks and balances. Moreover, the likelihood of transnational terrorism is reduced by democratic participation.

\subsection{The relevance of military expenditure and inclusive development in fighting terrorism}




\subsubsection{Linkage between military expenditure and terrorism}

The literature is tied to the reverse relationship in order to articulate how the extant literature is sparse on the positioning of the study. There are two main theoretical perspectives on the nexus between military spending and terrorism (Feridun \& Shahbaz, 2010). According to the first perspective, terrorism boosts military spending because more funds in defense are devoted to respond to increasing threats of terrorism. Hence, when military spending is the dependent variable, a positive relationship is anticipated. The second perspective reasons that increasing military expenditure is also anticipated to mitigate terrorism, considering that measures towards increasing military spending are motivated by the goal of combating terrorism. Therefore, from a theoretical angle, terrorism and defense spending portray a negative nexus when the former is the dependent variable.

From an empirical perspective, the underlying relationship is also very conflicting. There is some consensus in the literature that military expenditure does not necessarily mitigate terrorism (Feridun \& Shahbaz, 2010, p.195). In other words, measures of counterterrorism are counter-productive because they increase terrorism instead of preventing attacks (see Sandler, 2005). Moreover, the absence of comprehensive and common international long-term policies that can be used to fight terrorism renders country-specific counterterrorism policies ineffective (Omand, 2005). In addition, policies towards combating terrorism that are adopted by the countries such as the United States are not effective because such policies instead increase the probability of terrorism (Lum et al., 2006). Feridun and Shahbaz (2010) have established a uni-directional causality from terrorism to military expenditure. In the light of the above, the relationship between military expenditure and terrorism is still open to debate because of the absence of a consensus in empirical literature.

\subsubsection{Linkage between inclusive development and terrorism}

In this section, the literature is also tied to the reverse relationship in order to articulate how the extant literature is sparse on the positioning of the study. The theoretical relationship between terrorism and inclusive development can be engaged in three main strands: First, the relative deprivation theory that is developed by Gurr (1970) provides valuable insights into the nexus between terrorism and inclusive development (Krieger \& Meierrieks, 2015; Asongu et al., 2017a). If 'relative deprivation' can be defined as "individuals' expectations of economic or political goods exceed the actual distribution of those goods" (Piazza, 2006, p.162), then the theory "is grounded in the assumption that people who engage in rebellious political behavior are motivated principally by anger resulting from [...] relative deprivation" 
(Muller \& Weede, 1994, p. 40). Hence, rent seeking and confiscation of state resources by the elite (which is more pronounced in autocracies) can fuel frustration, anger and discontent over exclusive development. Such resentment could lead to aggression, political violence and terrorism. In situations of relative deprivation, the poor or marginalised can use violent means of making their grievances loud and clear. Moreover, there is some consensus in the microeconomic literature that features typical of exclusive development (e.g. inequality, unemployment and poverty) endow terrorists' entities with the opportunities of enriching their human resources with more qualified/skilled personnel (Bueno de Mesquita, 2005; Benmelech et al., 2012).

Second, in accordance with Asongu et al. (2017a), while exclusive development is directly linked to terrorism because of deprivation and frustration, the lack of inclusive development could also be indirectly linked to terrorism through dilapidating social conditions. For example, restricted socio-economic and politico-economic progress can further fuel terrorism.

The view of politico-economic participation is centered on the political influence of social segments in framing institutions for access by social groups to resources and distribution within society of these resources (Krieger \& Meierrieks, 2015). Under the scenario that power is withheld by a selected few, enough resources can be mobilised by them to create (or consolidate) institutions of politico-economic order that protect and promote their interests. Unhappy citizens at the lower socio-economic echelon then respond by violent means in order to change the institutional order or status quo. The employment of tactics of terror in the demand for more politico-economic participation has been substantially documented (Basuchoudhary \& Shughart, 2010; Gassebner \& Luechinger, 2011).

A plethora of socio-economic consequences have been documented to originate from inequality. As a case in point, Fosu $(2008,2009,2010 \mathrm{abc})$ has demonstrated that: inequality mitigates the accumulation of human capital that ultimately affects economic prosperity and that the response of poverty to growth is a decreasing function of socio-economic inequality. It follows that terrorism could result from inequality. The socio-economic oriented narrative is consistent with the literature which maintains that diminishing socio-economic conditions increase the use of violence by citizens to make the grievances known (see Caruso \& Schneider, 2011; Gries et al., 2011; Freytag et al., 2011).

Third, on the empirical front, the evidence is still very conflicting on the nexus between exclusive development and terrorism (or political violence) (Asongu et al., 2017a). No consensus has been established yet on the nexus between civil wars and inequality "Over 
the past few years, prominent large- $N$ studies of civil war seem to have reached a consensus that inequality does not increase the risk of civil war" (Østby, 2008, p. 143). Yet, some studies have established that the likelihood of civil wars increases with income-inequality (Cederman et al., 2011; Krieger \& Meierrieks, 2015; Baten \& Mumme, 2013).

With regards to the linkage between inequality and terrorism, evidence from empirical literature is also controversial. While some of the existing literature does not provide a clear nexus between terrorism and inequality (see Piazza, 2006; Abadie, 2006; Li, 2005), another strand of the literature has established inequality to be a fundamental cause of terrorism (Piazza, 2011; 2013). With regards to relationships between transnational (versus domestic terrorism) and inequality, it is believed that transnational terrorism is related to grievances in the foreign policy of developed countries (Savun \& Phillips, 2009), while domestic terrorism is considerably affected by grievances of an economic nature (Piazza, 2013).

Noticeably, the engaged literature has for the most part focused on the effect of governance on terrorism, the linkage between inclusive development and terrorism and the impact of military expenditure on terrorism. The present inquiry complements the existing literature by investigating the role of inclusive development and military expenditure in the effect of terrorism on governance.

\subsection{Intuition and theoretical underpinnings}

In this section, we discuss the theoretical intuition for the impact of terrorism on governance as well as the inclusion of interactions with inclusive growth and military expenditure. The discussion is articulated as follows: Firstly on the basis of the intuition and theoretical underpinnings as to why a country that is besieged by terrorist attacks could be concerned with the corresponding impact on governance (Laver \& Shepsle, 1998; Williams, 2012). Secondly on how the policy variables used in this study can be used to dampen the potentially negative effect of terrorism on governance.

Considering the effect of terrorism on governance in the light of the governance variables used in this study, three perspectives are articulated: (i) Due to changing interests in constituencies, terrorism events can affect policies that are adopted by political parties. Consistent with Indridason (2008), political coalitions can be created in the face of terrorism incidents in view of adopting common strategies and policies against the scourge. Hence, terrorism can influence the political climate as well as the political agenda of political parties. 
Accordingly, there is a bulk of literature on the perspective that terrorism influences election anticipation, given that governing parties are likely to be punished by voters if adequate policies are not implemented to protect them against the externalities of terrorism (Berrebi \& Klor, 2006; Siqueira \& Sandler, 2007). Thus, the fact that terrorism influences political governance within the frameworks of political stability/no violence and "voice \& accountability" has been confirmed in the literature (Indridason, 2008; Williams, 2012). Some examples in which terrorism has affected political governance (from the perspectives of political stability/no "voice and accountability) include: Turkey, where terrorism influences the outcome of political elections (Kibris, 2010) and the USA, in the aftermath of the September 11 attacks in 2001 (Langer \& Cohen, 2005; Jacobson, 2003).

(ii) Terrorism can affect economic governance (i.e. government effectiveness and regulation quality) because it shapes the ability of a government to formulate and implement policies that are necessary to promote the delivery of public goods and services. For instance, according to Tabor (2016), in the Delta region of Nigeria, the government has been constrained to improve the provision of public goods in the affected region.

(iii) From the perspective of institutional governance, the presence of terrorism decreases opportunities for corruption-control and respect of the rule of law. This is the case of Libya where the respect of the State and citizens of institutions that govern interactions between them is limited because of the prevailing levels of terrorism in the country. Moreover, the growth the Boko Haram of Nigeria is in regions where lawlessness is more apparent. Efobi and Asongu (2016) have recently established that terrorism increases corruption and decreases the rule of law. Asongu and Nwachukwu (2017b) show that terrorism negatively influences both political governance and economic governance.

Moreover, military expenditure and inclusive development have recently been established to mitigate terrorism. Asongu and Amankwah-Amoah (2018) have established that military expenditure can mitigate terrorism for positive development outcomes whereas Asongu et al. (2017a) have empirically demonstrated that military expenditure and inclusive development can effectively be used in the fight against terrorism.

\section{Data and Methodology}

\subsection{Data}

This study assesses a panel of 53 African countries with data for the period 1998-2012 from the Global Terrorism Database, African Development indicators (ADI) and World 
Governance Indicators of the World Bank and the terrorism incidents from Enders et al. (2011) and Gailbulloev et al. (2012). The investigated periodicity ends in 2012 due to data availability constraints, notably: terrorism variables from Enders et al. (2011) and Gailbulloev et al. (2012) and macroeconomic and institutional indicators from the ADI of the World Bank.

The periodicity begins from 1998 because governance variables from the World Governance Indicators are only available from the year 1996. The motivation for beginning in 1998 is to have a symmetric computation of three-year non-overlapping intervals (NOI). The interest of employing NOI is to restrict over-identification that could substantially bias estimated coefficients (see estimation technique section) and mitigate short-term disturbances that can substantially loom (Islam, 1995, p. 323). Therefore, we have five three-year NOI: 1998-2000; 2001-2003; 2004-2006; 2007-2009 and 2010-2012. It is important to note that the first-two data points consist of only two observations because there are missing observations for 1997, 1999 and 2001 in World Governance Indicators of the World Bank.

The dependent variables are six governance indicators from Kaufmann et al. (2010) that have been employed in recent governance and development literature (Gani, 2011; Asongu, 2015, 2016; Ajide \& Raheem, 2016; Andrés et al., 2015; Yerrabit \& Hawkes, 2015; Tchamyou, 2017). Full definitions have been provided in Section 2.1.

Two main terrorism variables are employed, namely: domestic and transnational terrorism. The definition of terrorism has also been provided in Section 2.1. Terrorismspecific definitions are from Efobi et al. (2015, p. 6). Domestic terrorism "includes all incidences of terrorist activities that involves the nationals of the venue country: implying that the perpetrators, the victims, the targets and supporters are all from the venue country" (p.6). Transnational terrorism is "terrorism including those acts of terrorism that concerns at least two countries. This implies that the perpetrator, supporters and incidence may be from/in one country, but the victim and target is from another". The terrorism variables capture the number of yearly terrorism incidents registered in a country within a year. In order to mitigate mathematical issues linked to log-transforming zeros and to correct the positive data skew, the study takes natural logarithms of terrorism incidents by adding one to the base. A similar approach to transformation has been recently used by Choi and Salehyan (2013), Bandyopadhyay et al. (2014) and Asongu et al. (2018b).

Two policy variables are employed, namely: inclusive development and military expenditure. The choice of military expenditure is consistent with Feridun and Shahbaz (2010), while the inclusive development indicator which is the inequality adjusted human 
development index (IHDI) is justified by a recent stream of literature maintaining that adherence to and sympathy for terrorists' organisations are fundamentally motivated by exclusive human development (Bass, 2014). Contemporary examples include Western-born and -educated youths joining the Islamic State of Iraq and Levant (ISIL) principally because they feel excluded in Western nations (Foster, 2014).

The choice of the IHDI as a proxy for inclusive development is consistent with recent African literature on inclusive development (Asongu et al., 2015). The IHDI represents the national average of achievements in three key areas, namely: knowledge; health and long life and decent standards of living. Beside, accounting for average rewards in terms of wealth, education and health, the IHDI also controls for the distribution of underlying achievements among the population by accounting for mean values of each dimension with regards to inequality.

In order to ensure that the estimated results are not biased by omitted variables, the study includes seven control variables: lagged governance indicator, inflation, education, Gross Domestic Product (GDP) growth, internet penetration, government expenditure and foreign direct investment (FDI). The quality of government has been documented to be positively related to information and communication technologies because they improve transparency and accountability (Snow, 2009; Boulianne, 2009; Diamond, 2010; Grossman et al., 2014). High income nations have been documented to be linked to better quality of government in Africa (Asongu, 2012, p. 191). From intuition, increasing prices is very likely to positively influence governance standards because authorities are prompted to device and implement policies that control for inflation. Financial globalisation within the framework of FDI positively affects political governance both in developing (Lalountas et al., 2011) and African (Asongu, 2014) countries. Cheung and Chan (2008) and Lederman et al. (2005) have established that increased schooling boosts governance standards. Governance is also strongly associated with government expenditure (Asongu \& Nwachukwu, 2016a). Definitions of variables are provided in Appendix 1, the summary statistics in Appendix 2 and the correlation matrix in Appendix 3.

\subsection{Methodology}

\subsubsection{Estimation specification}

Five principal reasons motivate the choice of a Generalized Method of Moments (GMM) (Asongu \& De Moor, 2017; Tchamyou et al., 2018). First, the governance variables should be persistent. This is the case because, as apparent in Appendix 4, the correlation 
between governance variables and their first lags are higher than the rule of thumb threshold of 0.800 that is needed to establish persistence in dependent variables. Second, the number of countries $(\mathrm{N})$ is higher than the number of years per country $(\mathrm{T})$. Hence, the sample of the study is consistent with the $\mathrm{N}(53)>\mathrm{T}(5)$ criterion. Third, the estimation strategy accounts for endogeneity in the all regressors. Fourth, cross-country differences are taken into account in the estimation technique. Fifth, small sample biases that are typical of the 'difference estimator' are controlled-for in the system GMM technique. It is essentially for this fifth reason that the system GMM estimator from Arellano and Bover (1995) and Blundell and Bond (1998) has been established to be better that the difference GMM estimator from Arellano and Bond (1991) (see Bond et al., 2001).

Within the framework of this inquiry, the Roodman (2009ab) extension of Arellano and Bover (1995) is adopted. In essence, instead of employing first differences, the estimation approach uses forward orthogonal deviations because the latter limits instrument proliferation (or restricts over-identification) and controls for cross-sectional dependence (see Baltagi, 2008; Love \& Zicchino, 2006; Boateng et al., 2018). A two-step estimation approach is adopted in place of the one-step strategy because it accounts for heteroscedasticity. It is interesting to note that the one-step approach is homoscedasticity-consistent.

The following equations in levels (1) and first difference (2) summarise the standard system GMM estimation procedure.

$$
\begin{aligned}
G_{i, t}=\sigma_{0}+ & \sigma_{1} G_{i, t-\tau}+\sigma_{2} T_{i, t}+\sigma_{3} P_{i, t}+\sigma_{4} T P_{i, t}+\sum_{h=1}^{6} \delta_{h} W_{h, i, t-\tau}+\eta_{i}+\xi_{t}+\varepsilon_{i, t} \\
G_{i, t}-G_{i, t-\tau}= & \sigma_{1}\left(G_{i, t-\tau}-G_{i, t-2 \tau}\right)+\sigma_{2}\left(T_{i, t}-T_{i, t-\tau}\right)+\sigma_{3}\left(P_{i, t}-P_{i, t-\tau}\right) \\
& +\sigma_{4}\left(T P_{i, t}-T P_{i, t-\tau}\right)+\sum_{h=1}^{6} \delta_{h}\left(W_{h, i, t-\tau}-W_{h, i, t-2 \tau}\right)+\left(\xi_{t}-\xi_{t-\tau}\right)+\left(\varepsilon_{i, t}-\varepsilon_{i, t-\tau}\right)
\end{aligned}
$$

where: $G_{i, t}$ is a governance indicator (political, economic or institutional governance) of country $i$ at period $t ; T_{i, t}$, is a terrorism variable (domestic and transnational); $P_{i, t}$, is a policy variable (inclusive development or military expenditure); $T P_{i, t}$, is the interaction between terrorism and a policy variable; $\sigma_{0}$ is a constant; $\tau$ represents the coefficient of autoregression; $W$ is the vector of control variables (internet penetration, GDP growth, inflation, foreign direct investment, education and government expenditure); $\eta_{i}$ is the country-specific effect; $\xi_{t}$ is the time-specific constant and $\varepsilon_{i, t}$ the error term. 


\subsubsection{Identification, simultaneity and exclusion restriction}

A robust GMM specification requires a discussion on issues pertaining to identification, simultaneity and exclusive restrictions. All independent indicators are suspected endogenous or predetermined variables (see Dewan \& Ramaprasad, 2014; Asongu $\&$ De Moor, 2017; Tchamyou, 2018). Hence, the gmmstyle is adopted for these variables and only years are treated as exogenous. The technique for treating the ivstyle (years) is 'iv(years, eq(diff))' because it is not likely for years to become endogenous in first-difference (see Roodman, 2009b).

In order to address the concern of simultaneity, lagged regressors are employed as instruments for forward-differenced variables. Accordingly, Helmet transformations are performed in order to eliminate fixed effects that could affect the examined relationships. This strategy which is consistent with Love and Zicchino (2006) and Tchamyou and Asongu (2017) consists of obtaining forward mean-differences of variables. Thus, instead of subtracting the previous observation for the contemporaneous one (see Roodman, 2009b, p. 104), the mean of all future observations are deducted from the variables.

The transformation enables orthogonal or parallel conditions between lagged values and forward-differenced values. Irrespective of the number of lags, in order to reduce data loss, with the exception of the last observation for each cross-section, the transformations are computed for all observations "And because lagged observations do not enter the formula, they are valid as instruments" (Roodman (2009b, p. 104). Hence, the System GMM specification is also designed to address the endogeneity problem associated with control variables.

In the light of the above, among instrumental variables, years are considered exclusively exogenous and hence, affect governance only through the endogenous explaining indicators. The statistical relevance of the exclusive restriction is investigated with the Difference in Hansen Test (DHT) for the exogeneity of instruments. In essence, the alternative hypothesis of the test should be rejected for the instruments to explain governance exclusively through the endogenous variables.

Accordingly, while in the standard instrumental variable (IV) approach, failure to reject the null hypothesis of the Sargan Overidentifying Restrictions (OIR) test means that the instruments do not elucidate the dependent variable beyond the endogenous explaining variables (see Beck et al., 2003; Asongu \& Nwachukwu, 2016b), in the GMM approach with forward orthogonal deviations, the DHT is the information criterion used to assess if years 
exhibit strict exogeneity by explaining the dependent variables exclusively via the proposed channels. Hence, the exclusion restriction is confirmed if the null hypothesis of the DHT corresponding to IV (year, eq(diff)) is not rejected.

\section{Empirical results}

\subsection{Presentation of results}

Table 1, Table 2 and Table 3 respectively present findings corresponding to political governance, economic governance and institutional governance. For all three tables, four principal information criteria are employed to assess the validity of the GMM model with forward orthogonal deviations. First, the alternative hypothesis of the second-order Arellano and Bond autocorrelation test $(\mathrm{AR}(2))$ in difference which argues for the absence of autocorrelation in the residuals should be rejected. Second, the null hypotheses of the Sargan and Hansen over-identification restrictions (OIR) tests should not be rejected because they are positions that instruments are valid or not correlated with the error terms. Accordingly, whereas the Sargan OIR test is not robust but not weakened by instruments, the Hansen OIR is robust but weakened by instruments. For the purpose of restricting identification or limiting the proliferation of instruments, we have ensured that for most specifications, instruments are lower than the number of cross-sections. Third, the Difference in Hansen Test (DHT) for exogeneity of instruments is also employed to assess the validity of results from the Hansen OIR test. Fourth, a Fisher test for the joint validity of estimated coefficients is also disclosed.

The findings are discussed in terms of marginal impacts and net effects and the latter effects are computed with the unconditional effect of terrorism and the conditional impact which is based on the interaction between the terrorism and policy variables. For instance in Table 1 on 'linkages between governance, terrorism and policy variables', in the second column, the unconditional impact of domestic terrorism is -0.072 , the conditional impact from the interaction between domestic terrorism and military expenditure is 0.034 , while the net effect of the role of 'military expenditure in domestic terrorism for political governance' is $0.0043([2.245 \times 0.034]+-0.072)^{3}$. This approach to net effect from interactive regressions is consistent with recent literature on the use of policy variables to modulate the effect of policy syndromes on development outcomes, notably: the role of information and communication

\footnotetext{
${ }^{3} 2.245$ is the mean value of military expenditure. It is important to note that, in the interpretation of findings from interactive regressions, we overlook the signs of constituents and focus on net effects because the concern of multicollinearity is overlooked in the specifications. Brambor et al. (2006) aptly discuss this concern of multicollinearity. It is also relevant to note that when variables with a high degree of substitution are entered into the same specification, there is a conflict and not all variables emerge from the regression output with the expected sign (see Beck et al., 2003). This is why net effects must be computed for an overall effect.
} 
technology (ICT) in mitigating the effect of environmental degradation on inclusive development (Asongu et al., 2017b) and the relevance of ICT in dampening the potentially negative effect of globalisation on environmental outcomes (Asongu, 2018).

The following main findings can be established for Table 1 on political governance and terrorism. The negative effect of domestic terrorism on voice and accountability is significantly mitigated by military expenditure because the marginal (or conditional) and net effects are positive. Most of the control variables are significant with expected signs.

Table 1: Political governance and terrorism

\begin{tabular}{|c|c|c|c|c|c|c|c|c|}
\hline & \multicolumn{8}{|c|}{ Dependent variable: Political Governance } \\
\hline & \multicolumn{4}{|c|}{ Voice and Accountability (VA) } & \multicolumn{4}{|c|}{ Political Stability (PS) } \\
\hline & \multicolumn{2}{|c|}{ Role of Military Expend. } & \multicolumn{2}{|c|}{ Role of Inclusive Dev. } & \multicolumn{2}{|c|}{ Role of Military Expend. } & \multicolumn{2}{|c|}{ Role of Inclusive Dev. } \\
\hline & $\begin{array}{l}\text { Domestic } \\
\text { Terror }\end{array}$ & $\begin{array}{l}\text { Trans. } \\
\text { Terror }\end{array}$ & $\begin{array}{l}\text { Domestic } \\
\text { Terror }\end{array}$ & $\begin{array}{l}\text { Trans. } \\
\text { Terror }\end{array}$ & $\begin{array}{l}\text { Domestic } \\
\text { Terror }\end{array}$ & $\begin{array}{l}\text { Trans. } \\
\text { Terror }\end{array}$ & $\begin{array}{l}\text { Domestic } \\
\text { Terror }\end{array}$ & $\begin{array}{l}\text { Trans. } \\
\text { Terror }\end{array}$ \\
\hline Constant & $\begin{array}{l}0.100 * * \\
(0.022)\end{array}$ & $\begin{array}{l}0.133 * \\
(0.051)\end{array}$ & $\begin{array}{l}-0.078 * \\
(0.082)\end{array}$ & $\begin{array}{l}-0.097 * * \\
(0.017)\end{array}$ & $\begin{array}{l}-0.418 * * * \\
(0.007)\end{array}$ & $\begin{array}{l}-0.170 * \\
(0.078)\end{array}$ & $\begin{array}{l}-0.175 * * \\
(0.027)\end{array}$ & $\begin{array}{l}-0.197 * * * \\
(0.003)\end{array}$ \\
\hline $\mathrm{VA}(-1)$ & $\begin{array}{l}0.971 * * * \\
(0.000)\end{array}$ & $\begin{array}{l}0.916 * * * \\
(0.000)\end{array}$ & $\begin{array}{l}0.977 * * * \\
(\mathbf{0 . 0 0 0 )}\end{array}$ & $\begin{array}{l}0.955 * * * \\
(0.000)\end{array}$ & --- & --- & --- & --- \\
\hline $\operatorname{PS}(-1)$ & -- & -- & -- & -- & $\begin{array}{l}0.851 * * * \\
(0.000)\end{array}$ & $\begin{array}{l}0.828 * * * \\
(0.000)\end{array}$ & $\begin{array}{l}0.843 * * * \\
(0.000)\end{array}$ & $\begin{array}{l}0.823 * * * \\
(0.000)\end{array}$ \\
\hline Domestic Terrorism (DT) & $\begin{array}{l}-0.072 * * * \\
(0.000)\end{array}$ & --- & $\begin{array}{l}-0.061 \\
(0.231)\end{array}$ & --- & $\begin{array}{l}-0.111^{* * *} \\
(0.002)\end{array}$ & -- & $\begin{array}{l}-0.175 \\
(0.179)\end{array}$ & -- \\
\hline Transnational Terrorism (TT) & --- & $\begin{array}{l}-0.085 * * * \\
(0.004)\end{array}$ & --- & $\begin{array}{l}-0.013 \\
(0.901)\end{array}$ & --- & $\begin{array}{l}-0.354 * * * \\
(0.000)\end{array}$ & --- & $\begin{array}{l}-0.350 * * \\
(0.016)\end{array}$ \\
\hline Military Expenditure & $\begin{array}{l}-0.018 \\
(0.437)\end{array}$ & $\begin{array}{l}-0.017 \\
(0.494)\end{array}$ & --- & -- & $\begin{array}{l}0.070 \\
(0.124)\end{array}$ & $\begin{array}{l}0.074 * * \\
(0.013)\end{array}$ & --- & -- \\
\hline Inclusive development & --- & -- & $\begin{array}{l}-0.045 \\
(0.272)\end{array}$ & $\begin{array}{l}-0.003 * * * \\
(0.000)\end{array}$ & --- & --- & $\begin{array}{l}-0.032 \\
(0.703)\end{array}$ & $\begin{array}{l}-0.0001 \\
(0.804)\end{array}$ \\
\hline Military Expenditure $\times$ DT & $\begin{array}{l}0.034 * * * \\
(0.000)\end{array}$ & --- & -- & -- & $\begin{array}{l}0.002 \\
(0.895)\end{array}$ & --- & -- & -- \\
\hline Inclusive development $\times$ DT & -- & --- & $\begin{array}{l}0.113 \\
(0.312)\end{array}$ & --- & -- & --- & $\begin{array}{l}0.084 \\
(0.715)\end{array}$ & --- \\
\hline Military Expenditure $\times$ TT & --- & $\begin{array}{l}-0.010 \\
(0.601)\end{array}$ & --- & --- & --- & $\begin{array}{l}-0.035 \\
(0.253)\end{array}$ & --- & --- \\
\hline Inclusive development $\times \mathrm{TT}$ & --- & -- & --- & $\begin{array}{l}-0.097 \\
(0.664)\end{array}$ & --- & -- & --- & $\begin{array}{l}-0.157 \\
(0.580)\end{array}$ \\
\hline Internet & $\begin{array}{l}0.008 * * * \\
(0.000)\end{array}$ & $\begin{array}{l}0.009 * * * \\
(0.000)\end{array}$ & $\begin{array}{l}0.002 * * \\
(0.021)\end{array}$ & $\begin{array}{l}0.003 * * * \\
(0.000)\end{array}$ & $\begin{array}{l}0.001 \\
(0.297)\end{array}$ & $\begin{array}{l}0.010 * * * \\
(0.000)\end{array}$ & $\begin{array}{l}-0.002 * * \\
(0.017)\end{array}$ & $\begin{array}{l}0.005 * * * \\
(0.000)\end{array}$ \\
\hline GDP growth & $\begin{array}{l}0.006 * \\
(0.085)\end{array}$ & $\begin{array}{l}0.001 \\
(0.814)\end{array}$ & $\begin{array}{l}0.005 \\
(0.322)\end{array}$ & $\begin{array}{l}0.007 \\
(0.207)\end{array}$ & $\begin{array}{l}0.017 * * * \\
(0.008)\end{array}$ & $\begin{array}{l}0.010 \\
(0.130)\end{array}$ & $\begin{array}{l}-0.002 \\
(0.524)\end{array}$ & $\begin{array}{l}-0.001 \\
(0.754)\end{array}$ \\
\hline Inflation & $\begin{array}{l}0.015 * * * \\
(0.000)\end{array}$ & $\begin{array}{l}0.013 * * * \\
(0.001)\end{array}$ & $\begin{array}{l}0.002 \\
(0.322)\end{array}$ & $\begin{array}{l}0.004 \\
(0.107)\end{array}$ & $\begin{array}{l}0.013 * * * \\
(0.000)\end{array}$ & $\begin{array}{l}0.015 * * * \\
(0.002)\end{array}$ & $\begin{array}{l}0.004 \\
(0.178)\end{array}$ & $\begin{array}{l}0.016 * * * \\
(0.000)\end{array}$ \\
\hline Foreign investment & $\begin{array}{l}-0.004 * * \\
(0.027)\end{array}$ & $\begin{array}{l}-0.001 \\
(0.586)\end{array}$ & $\begin{array}{l}-0.0007 \\
(0.656)\end{array}$ & $\begin{array}{l}-0.003 * * * \\
(0.005)\end{array}$ & $\begin{array}{l}-0.001 \\
(0.517)\end{array}$ & $\begin{array}{l}0.0008 \\
(0.822)\end{array}$ & $\begin{array}{l}-0.0002 \\
(0.922)\end{array}$ & $\begin{array}{l}-0.0007 \\
(0.880)\end{array}$ \\
\hline Education & $\begin{array}{l}-0.003 * * * \\
(0.001)\end{array}$ & $\begin{array}{l}-0.004 * * * \\
(0.000)\end{array}$ & $\begin{array}{l}-0.0002 \\
(0.581)\end{array}$ & $\begin{array}{l}-0.0006 \\
(0.146)\end{array}$ & $\begin{array}{l}0.002 * \\
(0.069)\end{array}$ & $\begin{array}{l}-0.003 * * * \\
(0.001)\end{array}$ & $\begin{array}{l}0.003 * * * \\
(0.000)\end{array}$ & $\begin{array}{l}-0.0001 \\
(0.537)\end{array}$ \\
\hline Government Expenditure & $\begin{array}{l}-0.0001 \\
(0.885)\end{array}$ & $\begin{array}{l}0.0006 * * \\
(0.029)\end{array}$ & $\begin{array}{l}0.0003 \\
(0.647)\end{array}$ & $\begin{array}{l}-0.0002 \\
(0.750)\end{array}$ & $\begin{array}{l}-0.002 * * * \\
(0.000)\end{array}$ & $\begin{array}{l}-0.001 * * * \\
(0.002)\end{array}$ & $\begin{array}{l}-0.002 * * * \\
(0.000)\end{array}$ & $\begin{array}{l}-0.0008 * * * \\
(0.001)\end{array}$ \\
\hline Net effects & 0.0043 & na & na & na & na & na & na & na \\
\hline $\operatorname{AR}(1)$ & $(0.016)$ & $(0.043)$ & $(0.002)$ & $(0.028)$ & $(0.104)$ & $(0.104)$ & $(0.082)$ & $(0.139)$ \\
\hline $\mathrm{AR}(2)$ & $(0.370)$ & $(0.772)$ & $(0.851)$ & $(0.967)$ & $(0.461)$ & $(0.858)$ & $(0.407)$ & $(0.977)$ \\
\hline Sargan OIR & $(0.531)$ & $(0.527)$ & $(0.124)$ & $(0.373)$ & $(0.054)$ & $(0.064)$ & $(0.031)$ & $(0.114)$ \\
\hline Hansen OIR & $(0.194)$ & $(0.289)$ & $(0.365)$ & $(0.369)$ & $(0.600)$ & $(0.523)$ & $(0.330)$ & $(0.325)$ \\
\hline $\begin{array}{l}\text { DHT for instruments } \\
\text { (a)Instruments in levels }\end{array}$ & & & & & & & & \\
\hline H excluding group & $(0.582)$ & $(0.593)$ & $(0.345)$ & $(0.708)$ & $(0.629)$ & $(0.395)$ & $(0.815)$ & $(0.727)$ \\
\hline $\begin{array}{l}\text { Dif(null, } \mathrm{H}=\text { exogenous) } \\
\text { (b) IV (years, eq(diff)) }\end{array}$ & $(0.112)$ & $(0.187)$ & $(0.401)$ & $(0.213)$ & $(0.493)$ & $(0.560)$ & $(0.145)$ & $(0.171)$ \\
\hline $\mathrm{H}$ excluding group & $(0.363)$ & $(0.540)$ & $(0.448)$ & $(0.507)$ & $(0.495)$ & $(0.647)$ & $(0.557)$ & $(0.292)$ \\
\hline Dif(null, $\mathrm{H}=$ exogenous) & $(0.061)$ & $(0.046)$ & $(0.195)$ & $(0.129)$ & $(0.780)$ & (0.164) & $(0.061)$ & $(0.479)$ \\
\hline $\begin{array}{l}\text { Fisher } \\
\text { Instruments }\end{array}$ & $\begin{array}{l}\text { 10814.02*** } \\
42\end{array}$ & $\begin{array}{l}\mathbf{1 4 8 7 7 . 3 * * *} \\
42\end{array}$ & $\begin{array}{l}122063 * * * \\
42\end{array}$ & $\begin{array}{l}\mathbf{2 5 6 3 2 5} * * * \\
42\end{array}$ & $\begin{array}{l}14527.81 * * * \\
42\end{array}$ & $\begin{array}{l}\mathbf{2 7 5 1 . 0 2 * * *} \\
42\end{array}$ & $\begin{array}{l}36204.3 * * * \\
42\end{array}$ & $\begin{array}{l}1.37 \mathrm{e}+7 * * * \\
42\end{array}$ \\
\hline
\end{tabular}


Constan

$\mathrm{RQ}(-1)$

GE(-1)

Domestic Terrorism (DT)

Transnational Terrorism (TT)

Military Expenditure

Inclusive development

Military Expenditure $\times$ DT

Inclusive development $\times$ DT

Military Expenditure×TT

Inclusive development $\times \mathrm{TT}$

Internet

GDP growth

Inflation

Foreign investment

Education

Government Expenditure

Net effects

$\mathrm{AR}(1)$

$\operatorname{AR}(2)$

Sargan OIR

Hansen OIR

DHT for instruments

(a)Instruments in levels

$\mathrm{H}$ excluding group

Dif(null, $\mathrm{H}=$ exogenous)

(b) IV (years, eq(diff))

$\mathrm{H}$ excluding group

Dif(null, $\mathrm{H}=$ exogenous)

Fisher

Instruments

Countries

Observations

\begin{tabular}{|c|c|c|c|c|c|c|c|}
\hline 44 & 44 & 43 & 43 & 44 & 44 & 43 & 43 \\
\hline 124 & 124 & 121 & 121 & 124 & 124 & 121 & 121 \\
\hline
\end{tabular}

mic governance and terrorism

\begin{tabular}{|c|c|c|c|c|c|c|c|}
\hline \multicolumn{8}{|c|}{ Dependent variable: Economic Governance } \\
\hline \multicolumn{4}{|c|}{ Regulation Quality (RQ) } & \multicolumn{4}{|c|}{ Government Effectiveness (GE) } \\
\hline \multicolumn{2}{|c|}{ Role of Military Expend. } & \multicolumn{2}{|c|}{ Role of Inclusive Dev. } & \multicolumn{2}{|c|}{ Role of Military Expend. } & \multicolumn{2}{|c|}{ Role of Inclusive Dev. } \\
\hline Domestic & Trans. & Domestic & Trans. & Domestic & Trans. & Domestic & Trans. \\
\hline Terror & Terror & Terror & Terror & Terror & Terror & Terror & Terror \\
\hline$-0.313^{* * *}$ & $-0.228^{* * *}$ & $-0.260 * * *$ & -0.034 & $-0.221^{* * *}$ & $-0.243 * * *$ & $-0.163 * * *$ & $-0.159^{* * *}$ \\
\hline$(0.000)$ & $(0.000)$ & $(0.000)$ & $(0.394)$ & $(0.000)$ & $(0.000)$ & $(0.002)$ & $(\mathbf{0 . 0 0 2})$ \\
\hline $\begin{array}{l}0.823 * * * \\
(0.000)\end{array}$ & $\begin{array}{l}0.904 * * * \\
(0.000)\end{array}$ & $\begin{array}{l}0.839 * * * \\
(0.000)\end{array}$ & $\begin{array}{l}0.888 * * * \\
(0.000)\end{array}$ & --- & --- & --- & --- \\
\hline --- & -- & -- & -- & $\begin{array}{l}0.938^{* * *} \\
(0.000)\end{array}$ & $\begin{array}{l}0.922 * * * \\
(0.000)\end{array}$ & $\begin{array}{l}0.873 * * * \\
(0.000)\end{array}$ & $\begin{array}{l}0.884 * * * \\
(0.000)\end{array}$ \\
\hline $\begin{array}{l}0.031 * * \\
(0.038)\end{array}$ & --- & $\begin{array}{l}-\mathbf{0 . 0 1 8} * * * \\
(\mathbf{0 . 0 0 5 )}\end{array}$ & --- & $\begin{array}{l}-0.025 \\
(0.140)\end{array}$ & --- & $\begin{array}{l}-0.145^{* * *} \\
(0.000)\end{array}$ & --- \\
\hline--- & $\begin{array}{l}0.044 \\
(0.342)\end{array}$ & --- & $\begin{array}{l}0.204 * * * \\
(0.000)\end{array}$ & --- & $\begin{array}{l}0.044 \\
(0.140)\end{array}$ & --- & $\begin{array}{l}0.032 \\
(0.628)\end{array}$ \\
\hline $\begin{array}{l}-0.016 \\
(0.334)\end{array}$ & $\begin{array}{l}0.049 * * * \\
(0.002)\end{array}$ & --- & --- & $\begin{array}{l}0.022 \\
(0.184)\end{array}$ & $\begin{array}{l}0.087 * * * \\
(0.000)\end{array}$ & --- & -- \\
\hline-- & -- & $\begin{array}{l}-0.004 * * * \\
(0.000)\end{array}$ & $\begin{array}{l}0.010 * * * \\
(0.000)\end{array}$ & -- & -- & $\begin{array}{l}-0.082 * * * \\
(0.000)\end{array}$ & $\begin{array}{l}0.001 * * * \\
(0.000)\end{array}$ \\
\hline $\begin{array}{l}0.006 \\
(0.493)\end{array}$ & --- & -- & --- & $\begin{array}{l}0.011 \\
(0.265)\end{array}$ & --- & --- & --- \\
\hline--- & --- & (omitted) & --- & --- & --- & $\begin{array}{l}0.229 * * * \\
(0.000)\end{array}$ & --- \\
\hline--- & $\begin{array}{l}-0.074 * * * \\
(0.001)\end{array}$ & --- & --- & --- & $\begin{array}{l}-0.109 * * * \\
(0.000)\end{array}$ & --- & --- \\
\hline --- & -- & --- & $\begin{array}{l}-0.621 * * * \\
(0.000)\end{array}$ & --- & -- & --- & $\begin{array}{l}-0.321 * * \\
(0.024)\end{array}$ \\
\hline $\begin{array}{l}-0.006^{* * *} \\
(0.023)\end{array}$ & $\begin{array}{l}0.0005 \\
(0.450)\end{array}$ & $\begin{array}{l}-\mathbf{- 0 . 0 0 1 * * *} \\
(\mathbf{0 . 0 0 0 )}\end{array}$ & $\begin{array}{l}0.005^{* * * *} \\
(0.000)\end{array}$ & $\begin{array}{l}-\mathbf{- 0 . 0 0 3 * * *} \\
(\mathbf{0 . 0 0 3 )}\end{array}$ & $\begin{array}{l}0.0002 \\
(0.819)\end{array}$ & $\begin{array}{l}-0.0008 \\
(0.172)\end{array}$ & $\begin{array}{l}0.001 * * \\
(0.030)\end{array}$ \\
\hline$-0.008^{* *}$ & $-0.005^{* *}$ & 0.003 & -0.005 & $0.008^{* *}$ & 0.0007 & 0.008 & 0.008 \\
\hline$(0.011)$ & $(0.042)$ & $(0.271)$ & $(0.155)$ & $(0.021)$ & $(0.795)$ & $(0.121)$ & $(0.117)$ \\
\hline 0.0009 & -0.001 & 0.0006 & $-0.003 * * *$ & 0.004 & 0.0003 & -0.002 & -0.0003 \\
\hline$(0.772)$ & $(0.612)$ & $(0.647)$ & $(0.002)$ & $(0.199)$ & $(0.880)$ & $(0.185)$ & $(0.723)$ \\
\hline $\begin{array}{l}0.001 \\
(0.187)\end{array}$ & $\begin{array}{l}0.004 * * * \\
(0.006)\end{array}$ & $\begin{array}{l}0.002 * * * \\
(0.002)\end{array}$ & $\begin{array}{l}0.001 * * \\
(0.034)\end{array}$ & $\begin{array}{l}-\mathbf{0 . 0 0 3} * * * \\
(\mathbf{0 . 0 0 0 )}\end{array}$ & $\begin{array}{l}-0.0008 \\
(0.397)\end{array}$ & $\begin{array}{l}-\mathbf{0 . 0 0 2} * * \\
(0.029)\end{array}$ & $\begin{array}{l}-0.001 \\
(0.161)\end{array}$ \\
\hline $0.007 * * *$ & $0.003 * * *$ & $0.003 * * *$ & -0.0001 & $0.002 * * *$ & $0.001 * *$ & $0.002 * * *$ & $0.001 \%$ \\
\hline$(0.000)$ & $(0.000)$ & $(0.000)$ & $(0.800)$ & $(0.001)$ & $(0.018)$ & $(0.000)$ & $(0.050)$ \\
\hline $\begin{array}{l}0.001 * * * \\
(0.000)\end{array}$ & $\begin{array}{l}0.001 * * * \\
(0.000)\end{array}$ & $\begin{array}{l}0.0007 * * * \\
(0.001)\end{array}$ & $\begin{array}{l}0.001 * * * \\
(0.000)\end{array}$ & $\begin{array}{l}0.0005 \\
(0.127)\end{array}$ & $\begin{array}{l}0.001 * * * \\
(0.000)\end{array}$ & $\begin{array}{l}-0.000005 \\
(0.986)\end{array}$ & $\begin{array}{l}0.0004 \\
(0.105)\end{array}$ \\
\hline na & na & na & -0.337 & na & na & 0.054 & na \\
\hline$(0.395)$ & $(0.172)$ & $(0.519)$ & $(0.112)$ & $(0.396)$ & $(0.197)$ & $(0.604)$ & $(0.625)$ \\
\hline$(0.038)$ & $(0.137)$ & $(0.639)$ & $(0.257)$ & $(0.133)$ & $(0.109)$ & $(0.146)$ & $(0.077)$ \\
\hline$(0.451)$ & (0.411) & $(0.011)$ & $(0.298)$ & $(0.006)$ & $(0.022)$ & $(0.001)$ & $(0.001)$ \\
\hline$(0.384)$ & $(0.438)$ & $(0.018)$ & $(0.700)$ & $(0.300)$ & $(0.289)$ & $(0.276)$ & $(0.337)$ \\
\hline
\end{tabular}

$\begin{array}{llllllll}\mathbf{( 0 . 6 8 5 )} & \mathbf{( 0 . 4 1 0 )} & \mathbf{( 0 . 6 4 8 )} & \mathbf{( 0 . 1 5 1 )} & \mathbf{( 0 . 6 8 6 )} & \mathbf{( 0 . 7 2 4 )} & \mathbf{( 0 . 5 8 4 )} & \mathbf{( 0 . 3 6 5 )} \\ \mathbf{( 0 . 2 3 6 )} & \mathbf{( 0 . 4 4 3 )} & (0.005) & \mathbf{( 0 . 9 4 3 )} & \mathbf{( 0 . 1 6 5 )} & \mathbf{( 0 . 1 4 5 )} & \mathbf{( 0 . 1 8 0 )} & \mathbf{( 0 . 3 5 2 )} \\ & & & & & & & \\ \mathbf{( 0 . 4 8 3 )} & \mathbf{( 0 . 3 1 5 )} & \mathbf{( 0 . 1 3 1 )} & \mathbf{( 0 . 5 8 7 )} & \mathbf{( 0 . 3 0 1 )} & \mathbf{( 0 . 3 4 2 )} & \mathbf{( 0 . 2 1 0 )} & \mathbf{( 0 . 2 7 6 )} \\ \mathbf{( 0 . 1 7 7 )} & \mathbf{( 0 . 8 8 3 )} & (0.005) & \mathbf{( 0 . 8 4 7 )} & \mathbf{( 0 . 3 5 5 )} & \mathbf{( 0 . 2 2 4 )} & \mathbf{( 0 . 6 6 7 )} & \mathbf{( 0 . 6 0 6 )} \\ \mathbf{1 1 4 0 . 1 6 * * * *} & \mathbf{3 2 2 0 . 9 4 * * *} & \mathbf{2 . 0 7 e + 6 * * *} & \mathbf{6 . 1 5 e}+\mathbf{6}^{* * *} & \mathbf{2 1 6 7 . 5 2 * * *} & \mathbf{9 7 7 8 . 0 5 * * *} & \mathbf{1 3 5 5 9 4 * * *} & \mathbf{2 9 0 8 3 0 * * *} \\ 42 & 42 & 42 & 42 & 42 & 42 & 42 & 42 \\ 44 & 44 & 43 & 43 & 44 & 44 & 43 & 43 \\ 124 & 124 & 121 & 121 & 124 & 124 & 121 & 121\end{array}$

${ }^{*}, * * * *$ : significance levels of $10 \%, 5 \%$ and $1 \%$ respectively. DHT: Difference in Hansen Test for Exogeneity of Instruments' Subsets. Dif: Difference. OIR: Over-identifying Restrictions Test. The significance of bold values is twofold. 1) The significance of estimated coefficients, Hausman test and the Fisher statistics. 2) The failure to reject the null hypotheses of: a) no autocorrelation in the AR(1) and AR(2) tests and; b) the validity of the instruments in the Sargan OIR test. na: not applicable because at least one coefficient needed for the computation of net effect is not significant. Omitted: omitted due to multicollinearity. Expend: Expenditure. Dev: Development. 


\begin{tabular}{|c|c|c|c|c|c|c|c|c|}
\hline & \multicolumn{8}{|c|}{ Dependent variable: Institutional Governance } \\
\hline & \multicolumn{4}{|c|}{ Rule of Law (RL) } & \multicolumn{4}{|c|}{ Corruption Control (CC) } \\
\hline & \multicolumn{2}{|c|}{ Role of Military Expend. } & \multicolumn{2}{|c|}{ Role of Inclusive Dev. } & \multicolumn{2}{|c|}{ Role of Military Expend. } & \multicolumn{2}{|c|}{ Role of Inclusive Dev. } \\
\hline & $\begin{array}{c}\text { Domestic } \\
\text { Terror } \\
\end{array}$ & $\begin{array}{l}\text { Trans. } \\
\text { Terror } \\
\end{array}$ & $\begin{array}{c}\text { Domestic } \\
\text { Terror } \\
\end{array}$ & $\begin{array}{l}\text { Trans. } \\
\text { Terror } \\
\end{array}$ & $\begin{array}{c}\text { Domestic } \\
\text { Terror } \\
\end{array}$ & $\begin{array}{l}\text { Trans. } \\
\text { Terror } \\
\end{array}$ & $\begin{array}{c}\text { Domestic } \\
\text { Terror } \\
\end{array}$ & $\begin{array}{c}\text { Trans. } \\
\text { Terror } \\
\end{array}$ \\
\hline Constant & $\begin{array}{l}-0.077 \\
(0.103)\end{array}$ & $\begin{array}{l}-0.076 * * \\
(0.043)\end{array}$ & $\begin{array}{l}-\mathbf{0 . 2 6 0 * * *} \\
(0.000)\end{array}$ & $\begin{array}{l}-\mathbf{0 . 1 3 3 * *} \\
(0.011)\end{array}$ & $\begin{array}{l}0.008 \\
(0.884)\end{array}$ & $\begin{array}{l}-0.032 \\
(0.415)\end{array}$ & $\begin{array}{l}-0.102 * * \\
(0.018)\end{array}$ & $\begin{array}{l}-0.007 \\
(0.863)\end{array}$ \\
\hline $\mathrm{RL}(-1)$ & $\begin{array}{l}0.890 * * * \\
(0.000)\end{array}$ & $\begin{array}{l}0.851 * * * \\
(0.000)\end{array}$ & $\begin{array}{l}0.839 * * * \\
(0.000)\end{array}$ & $\begin{array}{l}0.870 * * * \\
(0.000)\end{array}$ & --- & --- & --- & --- \\
\hline $\mathrm{CC}(-1)$ & --- & --- & -- & --- & $\begin{array}{l}0.885 * * * \\
(0.000)\end{array}$ & $\begin{array}{l}0.950 * * * \\
(0.000)\end{array}$ & $\begin{array}{l}\mathbf{0 . 8 3 2} * * * \\
(\mathbf{0 . 0 0 0 )}\end{array}$ & $\begin{array}{l}0.866 * * * \\
(0.000)\end{array}$ \\
\hline Domestic Terrorism (DT) & $\begin{array}{l}-0.071 * * * \\
(0.000)\end{array}$ & --- & $\begin{array}{l}-0.018 * * * \\
(0.005)\end{array}$ & --- & $\begin{array}{l}-0.001 \\
(0.927)\end{array}$ & --- & $\begin{array}{l}0.013 \\
(0.176)\end{array}$ & --- \\
\hline Transnational Terrorism (TT) & --- & $\begin{array}{l}-0.054 * * \\
(0.019)\end{array}$ & --- & $\begin{array}{l}-0.141 * * * \\
(0.009)\end{array}$ & --- & $\begin{array}{l}0.087 * * * \\
(0.002)\end{array}$ & --- & $\begin{array}{l}0.253 * * * \\
(0.005)\end{array}$ \\
\hline Military Expenditure & $\begin{array}{l}-0.034 * * * \\
(0.002)\end{array}$ & $\begin{array}{l}0.003 \\
(0.793)\end{array}$ & --- & --- & $\begin{array}{l}-0.079 * * * \\
(0.001)\end{array}$ & $\begin{array}{l}0.024 * * * \\
(0.008)\end{array}$ & --- & --- \\
\hline Inclusive development & --- & --- & $\begin{array}{l}-\mathbf{0 . 0 0 4} * * * \\
(\mathbf{0 . 0 0 0 )}\end{array}$ & $\begin{array}{l}-\mathbf{0 . 0 0 2} * * * \\
(\mathbf{0 . 0 0 0 )}\end{array}$ & -- & --- & $\begin{array}{l}-\mathbf{0 . 0 0 3} * * * \\
(\mathbf{0 . 0 0 0 )}\end{array}$ & $\begin{array}{l}-\mathbf{0 . 0 0 3}{ }^{* * *} \\
(\mathbf{0 . 0 0 0 )}\end{array}$ \\
\hline Military Expenditure $\times$ DT & $\begin{array}{l}0.049 * * * \\
(0.000)\end{array}$ & --- & --- & -- & $\begin{array}{l}0.019 * * \\
(0.015)\end{array}$ & --- & --- & --- \\
\hline Inclusive development $\times$ DT & --- & --- & (omitted) & --- & --- & --- & (omitted) & --- \\
\hline Military Expenditure $\times \mathrm{TT}$ & --- & $\begin{array}{l}-0.018 \\
(0.139)\end{array}$ & --- & --- & --- & $\begin{array}{l}-0.074 * * * \\
(0.000)\end{array}$ & --- & --- \\
\hline Inclusive development $\times \mathrm{TT}$ & --- & --- & -- & $\begin{array}{l}0.137 \\
(0.121)\end{array}$ & -- & --- & --- & $\begin{array}{l}-\mathbf{0 . 6 8 8} 8^{* * *} \\
(\mathbf{0 . 0 0 0 )}\end{array}$ \\
\hline Internet & $\begin{array}{l}-0.001 \\
(0.358)\end{array}$ & $\begin{array}{l}0.003 * * * \\
(0.000)\end{array}$ & $\begin{array}{l}-\mathbf{0 . 0 0 1} * * * \\
(0.000)\end{array}$ & $\begin{array}{l}0.001 * * * \\
(0.000)\end{array}$ & $\begin{array}{l}-0.003 \\
(0.137)\end{array}$ & $\begin{array}{l}0.001 \\
(0.396)\end{array}$ & $\begin{array}{l}-0.0007 \\
(0.505)\end{array}$ & $\begin{array}{l}0.002 * * * \\
(0.008)\end{array}$ \\
\hline GDP growth & $\begin{array}{l}-0.003 \\
(0.275)\end{array}$ & $\begin{array}{l}0.002 \\
(0.653)\end{array}$ & $\begin{array}{l}0.003 \\
(0.271)\end{array}$ & $\begin{array}{l}-0.0004 \\
(0.924)\end{array}$ & $\begin{array}{l}-0.006 \\
(0.116)\end{array}$ & $\begin{array}{l}-0.003 \\
(0.353)\end{array}$ & $\begin{array}{l}-0.013 * * * \\
(0.001)\end{array}$ & $\begin{array}{l}-0.010 * * * \\
(0.008)\end{array}$ \\
\hline Inflation & $\begin{array}{l}0.0005 \\
(0.784)\end{array}$ & $\begin{array}{l}0.0003 \\
(0.805)\end{array}$ & $\begin{array}{l}0.0006 \\
(0.647)\end{array}$ & $\begin{array}{l}0.002 \\
(0.147)\end{array}$ & $\begin{array}{l}-\mathbf{0 . 0 0 7 *} \\
(\mathbf{0 . 0 5 1 )}\end{array}$ & $\begin{array}{l}-0.010 * * * \\
(0.004)\end{array}$ & $\begin{array}{l}-\mathbf{0 . 0 1 0} * * * \\
(\mathbf{0 . 0 0 0 )}\end{array}$ & $\begin{array}{l}-0.010 * * * \\
(0.000)\end{array}$ \\
\hline Foreign investment & $\begin{array}{l}0.001 \\
(0.140)\end{array}$ & $\begin{array}{l}0.0008 \\
(0.317)\end{array}$ & $\begin{array}{l}0.002 * * * \\
(0.002)\end{array}$ & $\begin{array}{l}0.001 * * \\
(0.046)\end{array}$ & $\begin{array}{l}0.001 \\
(0.310)\end{array}$ & $\begin{array}{l}0.002 \% \\
(0.082)\end{array}$ & $\begin{array}{l}0.002 * * * \\
(0.000)\end{array}$ & $\begin{array}{l}0.0006 \\
(0.437)\end{array}$ \\
\hline Education & $\begin{array}{l}0.003 * * * \\
(0.004)\end{array}$ & $\begin{array}{l}0.00007 \\
(0.928)\end{array}$ & $\begin{array}{l}0.003 * * * \\
(0.000)\end{array}$ & $\begin{array}{l}0.0007 * \\
(0.099)\end{array}$ & $\begin{array}{l}0.003 * * \\
(0.018)\end{array}$ & $\begin{array}{l}0.0006 \\
(0.424)\end{array}$ & $\begin{array}{l}0.002 * * * \\
(0.000)\end{array}$ & $\begin{array}{l}0.0005 \\
(0.181)\end{array}$ \\
\hline Government Expenditure & $\begin{array}{l}0.0007 * * * \\
(0.001)\end{array}$ & $\begin{array}{l}0.001 * * * \\
(0.000)\end{array}$ & $\begin{array}{l}0.0007 * * * \\
(0.001)\end{array}$ & $\begin{array}{l}0.001 * * * \\
(0.000)\end{array}$ & $\begin{array}{l}0.001 * * * \\
(0.000)\end{array}$ & $\begin{array}{l}0.001 * * * \\
(0.000)\end{array}$ & $\begin{array}{l}0.001 * * * \\
(0.000)\end{array}$ & $\begin{array}{l}0.001 * * * \\
(0.000)\end{array}$ \\
\hline Net effects & 0.039 & na & na & na & na & -0.079 & na & -0.346 \\
\hline $\begin{array}{l}\operatorname{AR}(1) \\
\operatorname{AR}(2) \\
\text { Sargan OIR } \\
\text { Hansen OIR }\end{array}$ & $\begin{array}{l}(0.333) \\
(0.767) \\
(0.206) \\
(0.326)\end{array}$ & $\begin{array}{l}(\mathbf{0 . 1 0 4 )} \\
(\mathbf{0 . 4 5 4 )} \\
(0.009) \\
(\mathbf{0 . 3 1 3 )}\end{array}$ & $\begin{array}{l}(\mathbf{0 . 5 1 9 )} \\
\mathbf{( 0 . 6 3 9 )} \\
(0.011) \\
(\mathbf{0 . 0 1 8 )}\end{array}$ & $\begin{array}{l}(\mathbf{0 . 4 5 3 )} \\
(\mathbf{0 . 5 0 3 )} \\
(0.077) \\
(\mathbf{0 . 2 9 8 )}\end{array}$ & $\begin{array}{l}(0.061) \\
(\mathbf{0 . 6 8 0 )} \\
(\mathbf{0 . 8 6 7 )} \\
(\mathbf{0 . 3 3 1 )}\end{array}$ & $\begin{array}{l}(0.070) \\
(\mathbf{0 . 5 5 1 )} \\
(\mathbf{0 . 7 5 1 )} \\
(\mathbf{0 . 7 1 2 )}\end{array}$ & $\begin{array}{l}(0.089) \\
(\mathbf{0 . 4 8 0 )} \\
(\mathbf{0 . 5 4 6 )} \\
\mathbf{( 0 . 1 3 5 )}\end{array}$ & $\begin{array}{l}(0.099) \\
(\mathbf{0 . 3 3 1 )} \\
(\mathbf{0 . 2 7 3 )} \\
(\mathbf{0 . 2 0 7 )}\end{array}$ \\
\hline $\begin{array}{l}\text { DHT for instruments } \\
\text { (a)Instruments in levels } \\
\text { H excluding group } \\
\text { Dif(null, H=exogenous) } \\
\text { (b) IV (years, eq(diff)) } \\
\text { H excluding group } \\
\text { Dif(null, H=exogenous) }\end{array}$ & $\begin{array}{l}(0.464) \\
(0.280) \\
(0.261) \\
(0.627)\end{array}$ & $\begin{array}{l}(0.405) \\
(0.297) \\
\\
(0.413) \\
(0.157)\end{array}$ & $\begin{array}{l}(\mathbf{0 . 6 4 8 )} \\
(0.005) \\
(\mathbf{0 . 1 3 1 )} \\
(0.005)\end{array}$ & $\begin{array}{l}(0.329) \\
(0.328) \\
\\
(0.320) \\
(0.297)\end{array}$ & $\begin{array}{l}(0.536) \\
(0.251) \\
\\
(0.321) \\
(0.399)\end{array}$ & $\begin{array}{l}(0.577) \\
(0.668) \\
\\
(0.745) \\
(0.336)\end{array}$ & $\begin{array}{l}(\mathbf{0 . 4 0 4 )} \\
(\mathbf{0 . 1 0 6 )} \\
\\
(\mathbf{0 . 4 4 4 )} \\
(0.012)\end{array}$ & $\begin{array}{l}(\mathbf{0 . 2 0 0 )} \\
(\mathbf{0 . 3 0 6}) \\
\\
(\mathbf{0 . 4 9 0 )} \\
(0.026)\end{array}$ \\
\hline $\begin{array}{l}\text { Fisher } \\
\text { Instruments } \\
\text { Countries } \\
\text { Observations }\end{array}$ & $\begin{array}{l}\text { 33838.9*** } \\
42 \\
44 \\
124\end{array}$ & $\begin{array}{l}\mathbf{4 3 3 4 . 0 1} * * * \\
42 \\
44 \\
124\end{array}$ & $\begin{array}{l}\mathbf{2 . 0 7} \mathbf{e}+\mathbf{6} * * * \\
42 \\
43 \\
121\end{array}$ & $\begin{array}{l}\mathbf{5 1 7 2 4 . 9} \% * * \\
42 \\
43 \\
121\end{array}$ & $\begin{array}{l}\mathbf{1 3 2 9 . 7 8} * * * \\
42 \\
44 \\
124\end{array}$ & $\begin{array}{l}1904.75 * * * \\
42 \\
44 \\
124\end{array}$ & $\begin{array}{l}949900 * * * \\
42 \\
43 \\
121\end{array}$ & $\begin{array}{l}108926 * * * \\
42 \\
43 \\
121\end{array}$ \\
\hline
\end{tabular}

In Table 2 on the linkage between economic governance and terrorism, two specifications are invalid because either the instruments are invalid and/or autocorrelation is still apparent in the residuals. First, the net effect of inclusive development in reducing transnational (domestic) terrorism for better regulation quality (government effectiveness) is negative (positive). 
Second, there is some evidence of a negative threshold in the interaction between: (i) military expenditure and transnational terrorism for regulation quality on the one hand and government effectiveness on the other hand and; (ii) inclusive development and transnational terrorism for government effectiveness. A negative threshold effect is established when the unconditional effect of terrorism is not significant while the conditional effect from the interaction between a policy and terrorism is negative. In other words, a certain level of the policy variable is required for the underlying terrorism indicator to have an adverse effect on governance.

Most of the significant control variables display expected signs. Contingency of control variables on specifications is not uncommon as these also depend on the unobserved heterogeneity and specifications. The relevance of growth, education and internet penetration are contingent on the underlying. All these variables can both increase and decrease governance. There is no consensus on the effect of education on governance. Evidence on the absence of this consensus and corresponding studies arguing for both positive and negative effects is documented by Asongu and Nwachukwu (2016a). Moreover, the internet can be used to improve governance standards (e.g. through freedom of expression) or employed to decrease governance standards (e.g. via censorship). Finally, exclusive growth naturally decreases governance standards whereas inclusive growth has the opposite effect.

The following conclusions can be drawn from Table 3 on the linkage between institutional governance and terrorism: (i) the net effect of military expenditure in reducing domestic (resp. transnational) terrorism for enhanced rule of law (control of corruption) is positive (resp. negative); while the net impact of inclusive development in reducing transnational terrorism for better corruption-control is negative and; (ii) there is some evidence of a positive threshold in the interaction between military expenditure and domestic terrorism for more control of corruption. A positive threshold effect is established when the unconditional effect of terrorism is not significant, while the conditional effect from the interaction between a policy variable and terrorism is positive. In other words, a certain level of the policy variable is required for the underlying terrorism indicator to have a positive effect on governance.

\subsection{Further discussion of results and policy implications}

After comparing and contrasting the findings of Tables 1-3, two tendencies are worth elucidating further, notably: (i) the negative net effect on governance (regulation quality and corruption-control) when inclusive human development is used to reduce terrorism and (ii) 
the positive net impact on governance ("voice and accountability" and rule of law) when military expenditure is used to reduce domestic terrorism.

First, negative net effects from interactions with inclusive development show that there is a direct implication from exclusive development and an indirect implication from the role of the elite in policies of exclusive development. Inclusive development in the sampled countries may not be enough to mitigate the potentially negative effect of terrorism on governance. This is not surprising given that a recent World Bank report on the attainment of Millennium Development Goals (MDGs) extreme poverty target has revealed that extreme poverty has been decreasing in regions of the world with the exception of Africa where about $45 \%$ of the countries in the Sub-Saharan African region were still substantially off-track from the MDG extreme poverty target (World Bank, 2015). This is in sharp contrast to the appealing statistics of the continent enjoying more than two decades of growth resurgence that began in the mid 1990s (see Fosu, 2015; Kuada, 2015).

Further, the role of inclusive development in the overall negative effect could imply that in spite of sampled countries' efforts towards enhancing the equitable distribution of the fruits of economic growth, the impacts may be counter-productive owing to frustrations from some spheres of influence that are unsympathetic with the equitable distribution policies. The underlying influence is more likely among the elite who could be concerned that such redistributive policies negatively affect their interests. Within this framework, grievances and discontent over the inequitable distribution of the fruits of economic development is not from poor factions of the population. On the contrary, such resentment is from the elite that for the most part are situated in the upper- and middle-income strata. In essence, such elite could be concerned and infuriated over the more equitable distribution of economic resources and gains. The elite can also fund violent activities in view of creating instability so that eventually a terror-panic environment creates the necessary conditions for them to tailor and reinvent existing institutions to the protection of their rents and interests.

The above practical implication relating to inclusive development is broadly in accordance with narratives on the African middle class which is not sympathetic to concerns about inclusiveness because of her dependence on state resources and preference for specific markets (see Poulton, 2014). Moreover, the corresponding stand of literature is consistent with the perspective that the African middle class is very likely to employ skillful internal (e.g. civil unrest/war) and external tactics (e.g. terrorism) in view of hampering socioeconomic transformations, with the ulitmate ambition of maintaining a tight grip on politicoeconomic power (see Poulton, 2014: Resnick, 2015). Hence, in the light of the narrative, the 
elite and middle class could coordinate activities that result in temporal chaos and unrest with the goal of reinventing and tailoring institutions that work towards protecting their interests. The inference is in accordance with the perspective that such frustrations for midlle and upper classes are substantially associated with political connections by the elite, as opposed to the middle class and elite who are consolidating their income using level-playing filed activities like politically-free entreprising and innovation. The discouse is also in accordance with the skeptical narrative on the influence of the middle class in governance transformations in Africa (see Rodrik, 2015).

Second, the appealing role of the military spending in reducing the potentially negative effect of domesitc terrorism challenges the existing literature which maintains that military expenditure is insufficient in fighting terrorism because the effect might be counterproductive (see Sandler, 2005; Lum et al., 2006; Feridun \& Shahbaz, 2010).

The established evidence of terrorism significantly influencing governance is broadly consistent with studies which have shown that terror events affect political outcomes (Berrebi \& Klor 2006; Siqueira \& Sandler 2007), notably: terrorism affects the constitution of governments and voters' perspectives (Jacobson, 2003; Langer \& Cohen, 2005) and terrorism has some leverage on government survival (Indridason et al., 2008; Williams, 2012).

\section{Conclusion and further research directions}

The study has investigated the role of inclusive human development and military expenditure in the effect of terrorism on governance. It is based on 53 African countries for the period 1998-2012 and interactive Generalised Method of Moments is employed. Six governance indicators from the World Bank and two terrorism variables are used, namely: domestic and transnational terrorism dynamics. The following findings are established. First, on political governance, the negative effect of domestic terrorism on voice and accountability is significantly mitigated by military expenditure because the marginal (or conditional) and net effects are positive. Second, on economic governance, the net effect of inclusive development in reducing transnational (resp. domestic) terrorism for better regulation quality (government effectiveness) is negative (resp. positive). Third, with regards to institutional governance, the net effect of military expenditure in reducing domestic (resp. transnational) terrorism for enhanced rule of law (control of corruption) is positive (resp. negative) while the net impact of inclusive development in reducing transnational terrorism for better corruptioncontrol is negative. 
A caveat to this study is that governance variables are inherently subjective since they are based on perceptions. Another criticism put forward can be that the short periodicities do not capture changes for most countries, with the exception of countries which experience substantial governance crises and reforms. Unfortunately, the current data is limiting in that governance indicators are only available from the year 1996. As more data become available, the highlighted issues can be addressed in greater detail. This recommendation also extends to the issue of missing observations apparent in the study.

Given the diversity of signs and significance levels, the inference of causality may be questionable which could require the substitution of terms like "cause" or "effect" with terms like "association" or "link". The overall effect is based on net effects which may be positive and negative for certain government dynamics. Hence we do not expect the net effects to be uniform in sign. However, important tendencies (such as variations in the signs of net effects) emerge that raise important questions for future research.

\section{Appendices}

Appendix 1: Definitions of variables

\begin{tabular}{|c|c|c|c|}
\hline Variables & Signs & Definitions of variables (Measurement) & Sources \\
\hline Political Stability & PS & $\begin{array}{l}\text { "Political stability/no violence (estimate): measured as the } \\
\text { perceptions of the likelihood that the government will be } \\
\text { destabilized or overthrown by unconstitutional and violent } \\
\text { means, including domestic violence and terrorism" }\end{array}$ & World Bank (WDI) \\
\hline $\begin{array}{l}\text { Voice \& } \\
\text { Accountability }\end{array}$ & VA & $\begin{array}{l}\text { "Voice and accountability (estimate): measures the extent to } \\
\text { which a country's citizens are able to participate in selecting } \\
\text { their government and to enjoy freedom of expression, } \\
\text { freedom of association and a free media". }\end{array}$ & World Bank (WDI) \\
\hline $\begin{array}{l}\text { Government } \\
\text { Effectiveness }\end{array}$ & GE & $\begin{array}{l}\text { "Government effectiveness (estimate): measures the quality } \\
\text { of public services, the quality and degree of independence } \\
\text { from political pressures of the civil service, the quality of } \\
\text { policy formulation and implementation, and the credibility of } \\
\text { governments' commitments to such policies". }\end{array}$ & World Bank (WDI) \\
\hline $\begin{array}{l}\text { Regulation } \\
\text { Quality }\end{array}$ & RQ & $\begin{array}{l}\text { "Regulation quality (estimate): measured as the ability of the } \\
\text { government to formulate and implement sound policies and } \\
\text { regulations that permit and promote private sector } \\
\text { development". }\end{array}$ & World Bank (WDI) \\
\hline Rule of Law & $\mathrm{RL}$ & $\begin{array}{l}\text { "Rule of law (estimate): captures perceptions of the extent to } \\
\text { which agents have confidence in and abide by the rules of } \\
\text { society and in particular the quality of contract enforcement, } \\
\text { property rights, the police, the courts, as well as the likelihood } \\
\text { of crime and violence". }\end{array}$ & World Bank (WDI) \\
\hline $\begin{array}{l}\text { Corruption- } \\
\text { Control }\end{array}$ & $\mathrm{CC}$ & $\begin{array}{l}\text { "Control of corruption (estimate): captures perceptions of the } \\
\text { extent to which public power is exercised for private gain, } \\
\text { including both petty and grand forms of corruption, as well as } \\
\text { "capture' of the state by elites and private interests". }\end{array}$ & World Bank (WDI) \\
\hline Domestic & Domter & Number of Domestic terrorism incidents (in Ln) & Ender et al. (2011) \\
\hline
\end{tabular}




\begin{tabular}{|c|c|c|c|}
\hline terrorism & & & \\
\hline $\begin{array}{l}\text { Transnational } \\
\text { terrorism }\end{array}$ & Tranter & Number of Transnational terrorism incidents (in Ln) & $\begin{array}{l}\text { Gailbulloev et al. } \\
\qquad(2012)\end{array}$ \\
\hline $\begin{array}{l}\text { Inclusive } \\
\text { development }\end{array}$ & IHDI & Inequality Adjusted Human Development Index & UNDP \\
\hline Military Expense & Milit & Military Expenditure (\% of GDP) & World Bank (WDI) \\
\hline Internet & Internet & Internet penetration (per 100 people) & World Bank (WDI) \\
\hline Growth & GDPg & Gross Domestic Product (GDP) growth rates (annual \%) & World Bank (WDI) \\
\hline Inflation & Inflation & Consumer Price Index (annual \%) & World Bank (WDI) \\
\hline $\begin{array}{l}\text { Foreign } \\
\text { investment }\end{array}$ & FDI & Foreign direct investment net inflows (\% of GDP) & World Bank (WDI) \\
\hline Education & Educ & Secondary school enrolment (\% of Gross) & World Bank (WDI) \\
\hline $\begin{array}{l}\text { Government } \\
\text { Expenditure }\end{array}$ & G.Exp. & Government's Final Consumption Expenditure (\% of GDP) & World Bank (WDI) \\
\hline
\end{tabular}

WDI: World Bank Development Indicators. UNDP: United Nations Development Program. Ln: Natural logarithm.

\begin{tabular}{llllll}
\multicolumn{1}{l}{ Appendix 2: Summary statistics } & \multicolumn{1}{l}{} \\
\hline & Mean & SD & Minimum & Maximum & Observations \\
\cline { 2 - 6 } Political Stability & -0.551 & 0.929 & -3.297 & 1.087 & 265 \\
Voice \& Accountability & -0.679 & 0.723 & -2.155 & 1.009 & 265 \\
Government Effectiveness & -0.723 & 0.620 & -2.354 & 0.823 & 265 \\
Regulation Quality & -0.695 & 0.638 & -2.630 & 0.906 & 265 \\
Rule of Law & -0.706 & 0.660 & -2.595 & 1.032 & 265 \\
Control of Corruption & -0.602 & 0.577 & -1.848 & 0.971 & 265 \\
Domestic terrorism & 0.401 & 0.805 & 0.000 & 4.781 & 265 \\
Transnational terrorism & 0.203 & 0.451 & 0.000 & 2.802 & 265 \\
Inclusive development & 0.872 & 4.210 & 0.161 & 45.231 & 220 \\
Military Expenditure & 2.245 & 2.899 & 0.151 & 35.846 & 231 \\
Internet penetration & 4.766 & 8.022 & 0.002 & 51.174 & 264 \\
GDP growth & 4.706 & 4.230 & -8.149 & 32.265 & 259 \\
Inflation & 10.012 & 25.435 & -6.934 & 275.983 & 242 \\
Foreign direct investment & 5.125 & 7.175 & -4.265 & 52.398 & 259 \\
Education (secondary) & 42.416 & 25.022 & 5.608 & 111.454 & 201 \\
Government Expenditure & 8.715 & 22.623 & -62.668 & 206.7 & 206 \\
\hline
\end{tabular}

S.D: Standard Deviation. 


\section{Appendix 3: Correlation matrix}

\begin{tabular}{|c|c|c|c|c|c|c|c|c|c|c|c|c|c|c|c|c|}
\hline \multirow[b]{2}{*}{ PS } & \multicolumn{4}{|c|}{ Governance variables } & \multicolumn{2}{|c|}{ | } & \multicolumn{4}{|c|}{ Control variables } & \multicolumn{3}{|c|}{ Terrorism variables } & \multicolumn{2}{|c|}{ Policy variables } & \multirow[b]{3}{*}{ DS } \\
\hline & VA & $\mathrm{GE}$ & $\mathrm{RQ}$ & $\mathrm{CC}$ & RL & Internet & FDI & GDPg & Inflation & Educ & G.Exp. & Domter & Tranter & IHDI & Military & \\
\hline \multirow[t]{16}{*}{1.000} & 0.658 & 0.643 & 0.608 & 0.771 & 0.758 & 0.084 & 0.033 & -0.074 & -0.234 & 0.368 & -0.188 & -0.605 & -0.584 & 0.029 & -0.530 & \\
\hline & 1.000 & 0.719 & 0.730 & 0.715 & 0.773 & 0.187 & -0.092 & -0.184 & -0.049 & 0.390 & -0.126 & -0.263 & -0.276 & 0.204 & -0.266 & VA \\
\hline & & 1.000 & 0.890 & 0.872 & 0.892 & 0.303 & -0.178 & -0.184 & -0.112 & 0.570 & -0.143 & -0.225 & -0.271 & 0.237 & -0.245 & $\mathrm{GE}$ \\
\hline & & & 1.000 & 0.799 & 0.852 & 0.285 & -0.226 & -0.263 & -0.130 & 0.481 & -0.218 & -0.186 & -0.246 & 0.210 & -0.216 & RQ \\
\hline & & & & 1.000 & 0.888 & 0.224 & -0.099 & -0.269 & -0.166 & 0.523 & -0.172 & -0.294 & -0.335 & 0.207 & -0.312 & $\mathrm{CC}$ \\
\hline & & & & & 1.000 & 0.302 & -0.129 & -0.241 & -0.161 & 0.583 & -0.194 & -0.304 & -0.308 & 0.134 & -0.299 & RL \\
\hline & & & & & & 1.000 & -0.103 & -0.023 & -0.062 & 0.535 & -0.021 & 0.146 & 0.164 & 0.018 & 0.052 & Internet \\
\hline & & & & & & & 1.000 & 0.482 & 0.105 & -0.066 & 0.106 & -0.133 & -0.082 & -0.056 & -0.088 & FDI \\
\hline & & & & & & & & 1.000 & 0.124 & -0.220 & 0.249 & -0.006 & 0.007 & -0.078 & 0.157 & GDPg \\
\hline & & & & & & & & & 1.000 & -0.003 & 0.195 & 0.181 & 0.247 & 0.0002 & 0.030 & Inflation \\
\hline & & & & & & & & & & 1.000 & -0.061 & 0.036 & -0.071 & 0.240 & -0.082 & Educ \\
\hline & & & & & & & & & & & 1.000 & 0.095 & 0.221 & -0.038 & -0.042 & G.Exp. \\
\hline & & & & & & & & & & & & 1.000 & 0.699 & 0.090 & 0.661 & Domter \\
\hline & & & & & & & & & & & & & 1.000 & 0.052 & 0.107 & Tranter \\
\hline & & & & & & & & & & & & & & 1.000 & 0.052 & IHDI \\
\hline & & & & & & & & & & & & & & & 1.000 & Military \\
\hline
\end{tabular}


Appendix 4: Persistence of governance

\begin{tabular}{|c|c|c|c|c|c|c|}
\hline & PS & VA & GE & RQ & $\mathrm{CC}$ & $\mathrm{RL}$ \\
\hline PS(-1) & 0.925 & & & & & \\
\hline $\mathrm{VA}(-1)$ & & 0.953 & & & & \\
\hline $\mathrm{GE}(-1)$ & & & 0.965 & & & \\
\hline $\mathrm{RQ}(-1)$ & & & & 0.966 & & \\
\hline $\mathrm{CC}(-1)$ & & & & & 0.936 & \\
\hline RL(-1) & & & & & & 0.966 \\
\hline
\end{tabular}

\section{References}

Abadie, A., (2006). "Poverty, Political Freedom and the Roots of Terrorism." American Economic Review, 95 (2), pp. 50-56.

Ajide, K. B, \& Raheem, I. D., (2016). "Institutions-FDI Nexus in ECOWAS Countries". Journal of African Business, 17(3), pp. 319-341.

Alfa-Wali, M., Sritharan, K., Mehes, M., Abdullah, F., \& Rasheed, S., (2015). "Terrorismrelated trauma in Africa, an increasing problem", Journal of Epidemiology and Global Health, 5(2), pp. 201-203.

Asongu, S. A., and Amankwah-Amoah, J., (2018). "Mitigating capital flight through military expenditure: Insight from 37 African countries", Research in International Business and Finance, 45(October), pp. 38-53.

Andrés, A. R., Asongu, S. A., \& Amavilah, V. H. S., (2015). "The Impact of Formal Institutions on Knowledge Economy", Journal of the Knowledge Economy, 6(4), pp. 10341062.

Arellano, M., \& Bond, S., (1991). "Some tests of specification for panel data: Monte Carlo evidence and an application to employment equations". The Review of Economic Studies, 58(2), pp. 277-297.

Arellano, M., \& Bover, O., (1995). "Another look at the instrumental variable estimation of error-components models", Journal of Econometrics, 68(1), pp. 29-52.

Argomaniz, J., (2015). "European Union responses to terrorist use of the Internet", Cooperation and Conflict, 50 (2), pp. 250-268.

Asongu, S. A., (2012). "Government quality determinants of stock market performance in African countries", Journal of African Business, 13(3), pp. 183-199. 
Asongu, S. A., (2014). "Globalization (fighting), corruption and development : How are these phenomena linearly and nonlinearly related in wealth effects?", Journal of Economic Studies, 41(3), pp. 346-369.

Asongu, S. A., (2015). "On Taxation, Political Accountability and Foreign Aid: Empirics to a Celebrated Literature", South African Journal of Economics, 83(2), pp. 180-198.

Asongu, S. A., (2016). "Determinants of Growth in Fast Developing Countries: Evidence from Bundling and Unbundling Institutions", Politics \& Policy, 44(1), pp. 97-134.

Asongu, S. A., (2017). "Knowledge Economy Gaps, Policy Syndromes and Catch-up Strategies: Fresh South Korean Lessons to Africa”, Journal of the Knowledge Economy, 8(1), pp. 211-253.

Asongu, S. A., (2018). "ICT, openness and CO2 emissions in Africa", Environmental Science and Pollution Research, 25(10), pp. 9351-9359.

Asongu, S. A., \& De Moor, L., (2017). "Financial globalisation dynamic thresholds for financial development: evidence from Africa", The European Journal of Development Research, 29(1), pp. 192-212.

Asongu, S. A., Efobi, U., \& Beecroft, I., (2015). "Inclusive Human Development in Pre-Crisis Times of Globalisation-Driven Debts", African Development Review, 27(4), pp. 428-442.

Asongu, S. A., \& Nwachukwu, J. C., (2016a). "The Role of Lifelong Learning in Political Stability and Non-violence: Evidence from Africa”, Journal of Economic Studies, 43(1), pp. 141-164.

Asongu, S. A, \& Nwachukwu, J. C., (2016b). "Foreign aid and governance in Africa", International Review of Applied Economics, 30(1), pp. 69-88.

Asongu, S. A., \& Nwachukwu, J. C., (2017a). "Quality of Growth Empirics: Comparative Gaps, Benchmarking and Policy Syndromes", Journal of Policy Modeling, 39(5), pp. 861882.

Asongu, S. A, \& Nwachukwu, J. C., (2017b). "The Impact of Terrorism on Governance in African Countries”, World Development, 99(November), pp. 253-270.

Asongu, S. A., Tchamyou, V. S., Asongu, N., \& Tchamyou, N. P., (2017a). "The Comparative African Economics of Inclusive Development and Military Expenditure in Fighting Terrorism”. Journal of African Development, 19(2), pp. 77-91.

Asongu, S. A., Le Roux, S., \& Biekpe, N., (2017b). "Environmental degradation, ICT and inclusive development in Sub-Saharan Africa", Energy Policy, 111(December), pp. 353-361.

Asongu, S. A., Tchamyou, V. S., Minkoua, N, J. R., Asongu, N., \& Tchamyou, N. P., (2018a). "Fighting terrorism in Africa: Benchmarking policy harmonization", Physica A: Statistical Mechanics and its Applications, 492(February), pp. 1931-1957. 
Asongu, S. A., Tchamyou, V. S., Asongu, N., \& Tchamyou, N. P., (2018b). "Fighting terrorism in Africa: evidence from bundling and unbundling institutions", Empirical Economics. DOI: 10.1007/s00181-017-1378-3.

Baltagi, B. H., (2008). "Forecasting with panel data", Journal of Forecasting, 27(2), pp. 153173.

Bandyopadhyay, S., Sandler, T., \& Younas, J., (2014). "Foreign direct investment, aid, and terrorism", Oxford Economic Papers, 66(1), pp. 25-50.

Bang, J. T., \& Mitra, A. (2011). "Brain drain and institutions of governance: Educational attainment of immigrants to the US 1988-1998". Economic Systems, 35(2011), pp. 335-354.

Bass, L., (2014). "What Motivates European Youth to Join ISIS?”, Syria Comment, http://www.joshualandis.com/blog/push-factors-helping-isil-recruitment-loretta-bass/ (Accessed: 01/12/2015).

Basuchoudhary, A., \& Shughart, W.F. (2010). "On ethnic conflict and the origins of transnational terrorism". Defence and Peace Economics, 21(1), pp. 65-87.

Baten, J., \& Mumme, C. (2013). "Does inequality lead to civil wars? A global long-term study using anthropometric indicators (1816-1999)". European Journal of Political Economy, 32(December), pp. 56-79.

Beck, T., Demirgüç-Kunt, A., \& Levine, R., (2003), "Law and finance: why does legal origin matter?", Journal of Comparative Economics, 31(4), pp. 653-675.

Benmelech, E., Berrebi. C., \& Klor. E. F., (2012). "Economic Conditions and the Quality of Suicide Terrorism.” Journal of Politics, 74(1), pp. 113-128.

Berrebi, C., \& Klor, E., (2006). “On Terrorism and Electoral Outcomes”. Journal of Conflict Resolution, 50(6), pp. 899-925.

Blomberg, S. B., Hess, G. D., \& Weerapana, A., (2004). "Economic Conditions and Terrorism." European Journal of Political Economy, 20(2), pp. 463-478.

Blundell, R., \& Bond, S., (1998). "Initial conditions and moment restrictions in dynamic panel data models", Journal of Econometrics, 87(1), pp. 115-143.

Boateng, A., Asongu, S. A., Akamavi, R., \& Tchamyou, V. S., (2018). "Information Asymmetry and Market Power in the African Banking Industry", Journal of Multinational Financial Management, 44(March), pp. 69-83.

Bond, S., Hoeffler, A., \& Tample, J., (2001). "GMM Estimation of Empirical Growth Models", University of Oxford, Oxford.

Boulianne, S., (2009). "Does Internet Use Affect Engagement? A Meta-Analysis of Research", Political Communication, 26(2), pp. 193-211. 
Brambor, T., Clark, W. M., \& Golder, M., (2006). "Understanding Interaction Models:Improving Empirical Analyses", Political Analysis, 14(1), pp. 63-82.

Bueno de Mesquita E., (2005). "Quality of Terror.” American Journal of Political Science, 49 (3), pp. 515-530.

Caruso, R., \& Schneider, F., (2011). "The socio-economic determinants of terrorism and political violence in Western Europe (1994-2007)". European Journal of Political Economy, 27(S1), 37- 49.

Cederman, L.-E., Weidman, N.B., \& Gleditsch, K.S. (2011). "Horizontal inequalities and ethnonationalist civil war: A global comparison". American Political Science Review, 105(3), pp. 478-495.

Cheung, H.Y. \& Chan, A.W.H., (2008. "Corruption across countries; impacts form education and cultural dimensions”, The Social Science Journal, 45(2), pp. 223-239.

Choi, S-W., (2010). "Fighting Terrorism through the Rule of Law?", The Journal of Conflict Resolution, 54(6), pp. 940-966.

Choi, S-W., \& Salehyan , I., (2013). "No Good Deed Goes Unpunished: Refugees, Humanitarian Aid, and Terrorism", Conflict Management and Peace Sciences, 30(1), pp. 5375.

Clavarino, T., (2014). "Africa, the new outpost of terrorism", $R T$ op-edge. https://www.rt.com/op-edge/180996-africa-outpost-islamic-terrorism/ (Accessed: 20/01/2016).

Dewan, S., \& Ramaprasad, J., (2014). "Social media, traditional media and music sales", MIS Quarterly, 38(1), pp. 101-128.

Diamond, L., (2010). “Liberation Technology”, Journal of Democracy, 21(3), pp. 69-83.

Efobi, U., \& Asongu, S. A., (2016). "Terrorism and capital flight from Africa”, International Economics, 148(December), pp. 81-94.

Efobi, U., Asongu, S., \& Beecroft, I., (2015). "Foreign Direct Investment, Aid and Terrorism: Empirical Insight Conditioned on Corruption Control", African Governance and Development Institute Working Paper No. 15/007, Yaoundé.

Enders, W., \& Todd, S., (2006). The Political Economy of Terrorism. New York: Cambridge University Press.

Enders W, Sandler T \& Gaibulloev K., (2011). "Domestic versus transnational terrorism: Data, decomposition, and dynamics". Journal of Peace Research, 48(3), pp. 319-337.

Eubank, W. L., \& Weinberg, L., (1994). “Does Democracy Encourage Terrorism?” Terrorism and Political Violence, 6(4), pp.417-43. 
Eubank, W. L., \& Weinberg, L. B., (2001). "Terrorism and democracy: Perpetrators and victims". Terrorism and Political Violence, 13(1), pp. 155-164.

Eyerman, J., (1998). "Terrorism and Democratic States: Soft Targets or Accessible Systems.” International Interactions, 24(2), pp.151-170.

Fazel, A., (2013). "The growing terrorism threat in Africa", Mail \& Guardian, http:// mg.co.za/article/2013-12-17-the-growing-terrorism-threat-in-africa (Accessed: 20/01/2016).

Feridun, M., \& Shahbaz, M., (2010). "Fighting Terrorism: Are Military Measures Effective? Empirical Evidence from Turkey”, Defence \& Peace Economics, 21(2), pp. 193-205.

Findley, M. G., \& Young, J. K., (2011). “Terrorism, Democracy, and Credible Commitments.” International Studies Quarterly 55(2), pp.357-578.

Foster, P., (2014). "Jihadists from around the world flock to fight with Isil; UN", The Telegraph. http://www.telegraph.co.uk/news/worldnews/islamic-state/11200701/Jihadists-from-aroundthe-world-flock-to-fight-with-Isil-UN.html (Accessed: 01/12/2015).

Fosu, A. K., (2008). "Inequality and the Growth-Poverty Nexus: Specification Empirics Using African Data”, Applied Economics Letters, 15(7), pp. 563-566.

Fosu, A. K., (2009). "Inequality and the Impact of Growth on Poverty: Comparative Evidence for Sub-Saharan Africa”, Journal of Development Studies, 45(5), pp. 726-745.

Fosu, A. K., (2010a). "The Effect of Income Distribution on the Ability of Growth to Reduce Poverty: Evidence from Rural and Urban African Economies", American Journal of Economics and Sociology, 69(3), pp. 1034-1053.

Fosu, A. K., (2010b). "Does Inequality Constrain Poverty Reduction Programs? Evidence from Africa", Journal of Policy Modeling, 32(6), pp. 818-827.

Fosu, A. K., (2010c). "Inequality, Income and Poverty: Comparative Global Evidence", Social Sciences Quarterly, 91(5), pp. 1432-1446.

Fosu, A., (2013). "Growth of African Economies: Productivity, Policy Syndromes and the Importance of Institutions”, Journal of African Economies, 22(4), pp. 523-551.

Fosu, A. K., (2015a). "Growth, Inequality and Poverty in Sub-Saharan Africa: Recent Progress in a Global Context”, Oxford Development Studies, 43(1), pp. 44-59.

Freytag, A., Krüger, J.J., Meierrieks, D., Schneider, F. (2011). "The origins of terrorism: Cross-country estimates of socio-economic determinants of terrorism". European Journal of Political Economy, 27(S1), pp. 5-16.

Gailbulloev, K., Sandler, T., \& Santifort, C., (2012). "Assessing the Evolving Threat of Terrorism”, Global Policy, 3(2), pp. 135-144. 
Gani, A., (2011). "Governance and Growth in Developing Countries", Journal of Economic Issues, 45(1), pp. 19-40.

Gassebner, M., \& Luechinger, S., (2011). "Lock, Stock, and Barrel: A Comprehensive Assessment of the Determinants of Terror." Public Choice, 149 (3-4), pp. 235-261.

Gause, F G. III., (2005). “Can democracy stop terrorism?” Foreign Affairs, 84(5), pp. 62-76.

Gries, T., Krieger, D., \& Meierrieks, D. (2011). "Causal linkages between domestic terrorism and economic growth". Defence and Peace Economics, 22(5), pp. 493-508.

Grossman, G., Humphreys, M., and Sacramone-Lutz, G., (2014). "“I wld like u WMP to extend electricity 2 our village": On Information Technology and Interest Articulation", American Political Science Review, 108(3), pp. 688-705.

Gurr, T.R. (1970). Why Men Rebel. Princeton University Press: Princeton.

Hoffman, A. M., Shelton, C., \& Cleven, E., (2013). "Press Freedom, Publicity, and the CrossNational Incidence of Transnational Terrorism", Political Research Quarterly, 66 (4), pp. 896-909.

Indridason, I. H., (2008). "Does Terrorism Influence Domestic Politics? Coalition Formation and Terrorist Incidents", Journal of Peace Research, 45(2), pp. 241-259.

Jacobson, G. C., (2003). "Terror, Terrain, and Turnout: Explaining the 2002 Midterm Elections”. Political Science Quarterly, 118 (1), pp. 1-22.

Jolliffe, I. T. (2002) Principal Component Analysis (2nd Ed.) New York: Springer.

Jong-a-Pin, R., (2009). "On the measurement of political instability and its impact on economic growth", The European Journal of Polical Economy, 25(1), pp. 15-29.

Kaiser, H. F. (1974) “An index of factorial simplicity” Psychometrika, 39(1), pp. 3-36.

Kaufmann, D., Kraay, A \& Mastruzzi, M., (2010). “The worldwide governance indicators: Methodology and analytical Issues". World Bank Policy Research Working Paper No 5430, Washington.

Kibris, A., (2010). “Terrorism, Elections and Ethnicity”. Working Paper, Sabanci University.

Krieger, T., \& Meierrieks, D., (2015). "Does Income Inequality Lead to Terrorism? Evidence from the Post-9/11 Era", Discussion Paper Series, Wilfried Guth Endowed Chair for Constitutional Political Economy and Competition Policy, University of Freiburg, No. 201504.

Krueger, A. B., \& Maleckova. J., (2003). "Education, Poverty, and Terrorism: Is There a Causal Connection?” Journal of Economic Perspectives, 17(4), pp. 119-144.

Kuada, J., (2015). Private Enterprise-Led Economic Development in Sub-Saharan Africa The Human Side of Growth First edition by Kuada, J, Palgrave Macmillan: New York. 
Kuncic, A. (2014). "Institutional Quality Dataset," Journal of Institutional Economics, 10(1), pp.135-161.

Lai, B., (2007). “'Draining the Swamp': An Empirical Examination of the Production of International Terrorism, 1968-1998." Conflict Management and Peace Science,24(4), pp. 297-310.

Lalountas, D.A., Manolas, G.A., \& Vavouras, I. S., (2011), “Corruption, globalization and development: how are these three phenomena related?", Journal of Policy Modeling, 33(4), pp. 636-648.

Langbein, L., \& Knack, S., (2010). "The Worldwide Governance Indicators: Six, One, or None?", The Journal of Development Studies, 46(2),pp. 350-370.

Langer, G., \& Cohen, J., (2005). "Voters and Values in the 2004 Election", Public Opinion Quarterly, 69 (5), pp. 744-759.

Laver, M., \& Shepsle, K. A., (1998). "Events, Equilibria, and Government Survival". American Journal of Political Science, 42(1), pp. 28-54

Lederman, D., Loayza, N.V., \& Soares, R.R. (2005), “Accountability and corruption: political institutions matter”, Economics \& Politics, 7(1), pp. 1-35.

Lee, C-Y., (2013). "Democracy, civil liberties and hostage-taking terrorism", Journal of Peace Research, 50(2), pp. 235-248.

Li, Q., (2005). "Does Democracy Promote or Reduce Transnational Terrorist Incidents?" Journal of Conflict Resolution 49(2), pp.278-297.

Li, Q., \& Schaub, D., (2004). "Economic Globalization and Transnational Terrorism", Journal of Conflict Resolution, 48(2), pp. 230-258.

Love, I., \& Zicchino, L., (2006). "Financial Development and Dynamic Investment Behaviour: Evidence from Panel VAR". The Quarterly Review of Economics and Finance, 46(2), pp. 190-210.

Lum, C., Kennedy, L.W., \& Sherley, A. J. (2006). “The effectiveness of counter-terrorism strategies. A Campbell Systematic Review", Crime and Justice, 2(2), pp.1-49.

Muller, E.N., \& Weede, E. (1994). "Theories of rebellion: Relative deprivation and power contention". Rationality and Society, 6(1), pp. 40-57.

Omand, D., (2005). "Countering international terrorism: the use of strategy". Survival, 47(4), pp. 107-116.

Østby, G., (2008). "Polarization, horizontal inequalities and violent civil conflict". Journal of Peace Research, 45(2), pp.143-162.

Piazza, J. A., (2006). "Rooted in Poverty? Terrorism, Poor Economic Development, and 
Social Cleavages.” Terrorism and Political Violence, 18 (1), pp. 159-77.

Piazza, J., (2007). "Draining the Swamp: Democracy Promotion, State Failure, and Terrorism in 19 Middle Eastern States." Studies in Conflict and Terrorism, 30(6), pp. 521-539.

Piazza, J., (2008a). "Incubators of Terror: Do Failed and Failing States Promote Transnational Terrorism?” International Studies Quarterly, 52(3), pp.468-488.

Piazza, J., (2008b). "Do democracy and free markets protect us from terrorism?" International Politics, 45(1), pp. 72-91.

Piazza, J. A., (2011). "Poverty, Minority Economic Discrimination and Domestic Terrorism", Journal of Peace Research, 48 (3), pp. 339-353.

Piazza, J. A., (2013). "The Cost of Living and Terror: Does Consumer Price Volatility Fuel Terrorism?” Southern Economic Journal, 79 (4), pp. 812-831.

Poulton, C., (2014). "Democratisation and the Political Incentives for Agricultural Policy in Africa”. Development Policy Review, 32(S2), pp. S101-S122.

Resnick, D., (2015). "The Political Economy of Africa's Emergent Middle Class: Retrospect and Prospects", Journal of International Development, 27(5), pp. 573-587.

Rodrik, D., (2015). "Premature Deindustrialization", IAS School of Social Science Economic Working Paper No. 107, Princeton University, Princeton.

Roodman, D., (2009a). “A Note on the Theme of Too Many Instruments", Oxford Bulletin of Economics and Statistics, 71(1), pp. 135-158.

Roodman, D., (2009b). "How to do xtabond2: An introduction to difference and system GMM in Stata", Stata Journal, 9(1), pp. 86-136.

Ross, J. I., (1993). "Structural causes of oppositional political terrorism: Towards a causal model". Journal of Peace Research, 30(3), pp. 317-329.

Sandler, T. (2005). "Collective versus unilateral responses to terrorism". In Policy Challenges and Political Responses, Springer USA, pp. 75-93. DOI: 10.1007/0-387-28038-3_5.

Savun, B., \& Phillips, B. J., (2009). "Democracy, foreign policy, and terrorism”. Journal of Conflict Resolution, 53(6), pp. 878-904.

Siqueira, K., \& Sandler, T., (2007). "Terrorist Backlash, Terrorism Mitigation, and Policy Delegation”. Journal of Public Economics, 91 (9), pp. 1800-1815.

Schmid, A. P., (1992). "Terrorism and Democracy." Terrorism and Political Violence, 4(4), pp.14-25.

Snow, B. C., (2009). "Mobile Phone Diffusion and Corruption in Africa", Political Communication, 26(3), pp.333-353. 
Straus, S., (2012). "Wars do end. Changing Patterns of Political Violence in Sub-Saharan Africa", African Affairs, 111(443), pp. 179-201.

Tabor, J. O., (2016). "Terrorism or clamor for resource control: An analysis of Nigeria's Niger Delta militants", Journal of Terrorism Research, 7(3), pp. 23-34.

Tchamyou, V. S., (2017). "The Role of Knowledge Economy in African Business", Journal of the Knowledge Economy, 8(4), pp. 1189-1228.

Tchamyou, V. S., (2018). "Education, Lifelong learning, Inequality and Financial access:

Evidence from African countries", Contemporary Social Science. DOI:

$10.1080 / 21582041.2018 .1433314$.

Tchamyou, V. S., \& Asongu, S. A., (2017). "Information Sharing and Financial Sector Development in Africa" Journal of African Business, 18(7), pp. 24-49.

Tchamyou, V. S., Asongu, S. A., \& Nwachukwu, J. C., (2018). "Effects of asymmetric information on market timing in the mutual fund industry", International Journal of Managerial Finance. DOI: 10.1108/IJMF-09-2017-0187.

Weinberg, L. B., \& Eubank, W. L., (1998). "Terrorism and democracy: What recent events disclose?” Terrorism and Political Violence, 10(1), pp. 108-118.

Williams, L. K., (2012). "The Political Consequences of Terrorism: Terror Events, Casualties, and Government Duration”, International Studies Perspectives, (2012), pp. 1-19.

Windsor, J. L., (2003). "Promoting democratization can combat terrorism”. Washington Quarterly, 26(3), pp. 43-58.

World Bank (2015). “World Development Indicators', World Bank Publications http://www.gopa.de/fr/news/world-bank-release-world-development-indicators-2015

(Accessed: 25/04/2015).

Yerrabati, S., \& Hawkes, D., (2015). "Economic Governance and Economic Growth in South and East Asia \& Pacific Region: Evidence from Systematic Literature Reviews and Metaanalysis". Advances in Economics and Business, 3(1), pp. 1 - 21. 